\title{
A Shape-Persistent Cryptand for Capturing Polycyclic Aromatic Hydrocarbons (PAHs)
}

\author{
Rui-Feng Zhang, Wen-Jing Hu, Yahu A. Liu, Xiao-Li Zhao, \\ Jiu-Sheng Li, * Biao Jiang* and Ke Wen* \\ Shanghai Advanced Research Institute, Chinese Academy of Science, Shanghai 201210, P. R. China \\ Medicinal Chemistry, ChemBridge Research Laboratories, San Diego, CA 92127, USA \\ Shanghai Key Laboratory of Green Chemistry and Chemical Processes, and Department of Chemistry, \\ East China Normal University, Shanghai 200062, P. R. China
}

\section{Correspondence Address}

Prof. Ke Wen

Shanghai Advanced Research Institute, Chinese Academy of Science

No. 100 Haike Road, Zhangjiang Hi-Tech Park, Pudong, Shanghai, 201210 P. R. China

E-mail: wenk@sari.ac.cn 
Figure S1. ${ }^{1}$ H NMR spectrum of 2 in DMSO- $d_{6} \quad$ S4

Figure S2. ${ }^{13} \mathrm{C}$ NMR spectrum of 2 in DMSO- $d_{6} \quad$ S4

Figure S3. HRMS (ESI) of 2

Figure S4. ${ }^{1} \mathrm{H}$ NMR spectrum of 3 in $\mathrm{CDCl}_{3} \quad \mathrm{S5}$

Figure S5. ${ }^{13} \mathrm{C}$ NMR spectrum of 3 in $\mathrm{CDCl}_{3} \quad$ S6

Figure S6. HRMS (ESI) of $3 \quad$ S6

Figure S7. ${ }^{1} \mathrm{H}$ NMR spectrum of 4 in $\mathrm{CDCl}_{3} \quad$ S7

Figure S8. ${ }^{13} \mathrm{C}$ NMR spectrum of 4 in $\mathrm{CDCl}_{3} \quad \mathrm{S7}$

$\begin{array}{lr}\text { Figure S9. HRMS (ESI) of } 4 & \text { S8 }\end{array}$

Figure S10. ${ }^{1} \mathrm{H}$ NMR spectrum of 5 in $\mathrm{CDCl}_{3} \quad S 8$

Figure S11. ${ }^{13} \mathrm{C}$ NMR spectrum of 5 in $\mathrm{CDCl}_{3} \quad$ S9

$\begin{array}{ll}\text { Figure S12. HRMS (ESI) of } 5 & \text { S9 }\end{array}$

Figure S13. ${ }^{1} \mathrm{H}$ NMR spectrum of 1 in $\mathrm{CDCl}_{3} \quad \mathbf{S 1 0}$

Figure S14. ${ }^{13} \mathrm{C}$ NMR spectrum of 1 in $\mathrm{CDCl}_{3} \quad \mathrm{S10}$

$\begin{array}{ll}\text { Figure S15. HRMS (ESI) of } 1 & \text { S11 }\end{array}$

Figure S16. ${ }^{1} \mathrm{H}$ NMR spectra of mixed solution of 1 and $6 \quad S 12$

Figure S17. Partial 2D NOESY spectra of mixed solution of 1 and $6 \quad$ S12

Figure S18. Job plot of the complex between 1 and $6 \quad$ S13

$\begin{array}{ll}\text { Host-guest complexation of } 1 \text { and } \mathrm{G} \text { in } \mathrm{CDCl}_{3} & \mathrm{S13}\end{array}$

Figure S19. ${ }^{1}$ H NMR spectra of 1 with different molar ratio of $6 \quad$ S14

Figure S20. NMR titrations for the complexation of 1 and $6 \quad$ S14

$\begin{array}{ll}\text { Figure S21. } & { }^{1} \text { H NMR spectra of mixed solution of } 1 \text { and } 7 \\ \text { S15 }\end{array}$

Figure S22. Partial 2D NOESY spectra of mixed solution of 1 and $7 \quad$ S15

$\begin{array}{ll}\text { Figure S23. Job plot of the complex between } 1 \text { and } 7 & \text { S16 }\end{array}$

Figure S24. ${ }^{1} \mathrm{H}$ NMR spectra of 1 with different molar ratio of $7 \quad$ S16 
Figure S25. NMR titrations for the complexation of 1 and 8

Figure S26. ${ }^{1}$ H NMR spectra of mixed solution of 1 and 8

Figure S27. Partial 2D NOESY spectra of mixed solution of 1 and 8

Figure S28. Job plot of the complex between 1 and 8

Figure S29. ${ }^{1} \mathrm{H}$ NMR spectra of 1 with different molar ratio of 8

Figure S30. NMR titrations for the complexation of 1 and 8

Figure S31. ${ }^{1} \mathrm{H}$ NMR spectra of mixed solution of 1 and 9

Figure S32. Partial 2D NOESY spectra of mixed solution of 1 and 9

Figure S33. Job plot of the complex between 1 and 9

Figure S34. ${ }^{1} \mathrm{H}$ NMR spectra of 1 with different molar ratio of 9

Figure S35. NMR titrations for the complexation of 1 and 9

Figure S36. HRMS (ESI) of host-guest complex 9с1

Figure S37. ${ }^{1} \mathrm{H}$ NMR spectra of mixed solution of 1 and 9

Figure S38. Partial 2D NOESY spectra of mixed solution of 1 and 9

Figure S39. Job plot of the complex between 1 and 9

Figure S40. ${ }^{1} \mathrm{H}$ NMR spectra of 1 with different molar ratio of 9

Figure S41. NMR titrations for the complexation of 1 and 9

Figure S42. HRMS (ESI) of host-guest complex 9с1

Figure S43. ${ }^{1} \mathrm{H}$ NMR spectrum of the crystals $6 \subset 1$ in DMSO-d 6

Figure S44. Thermal atomic displacement ellipsoid plot of 1 and the description of the crystal parameters and refinement metrics

Figure S45. Thermal atomic displacement ellipsoid plot of $1+6$ and the description of the crystal parameters and refinement metrics 


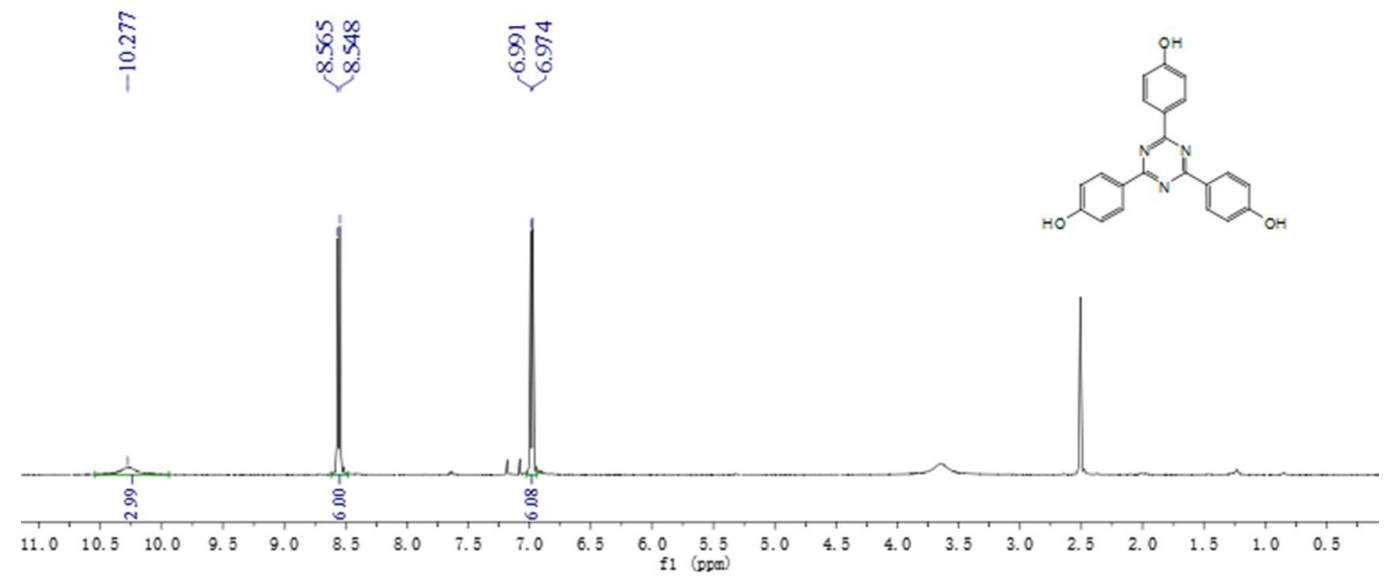

Figure S1. ${ }^{1} \mathrm{H}$ NMR $(500 \mathrm{MHz})$ of 2 in DMSO- $d_{6}$ 


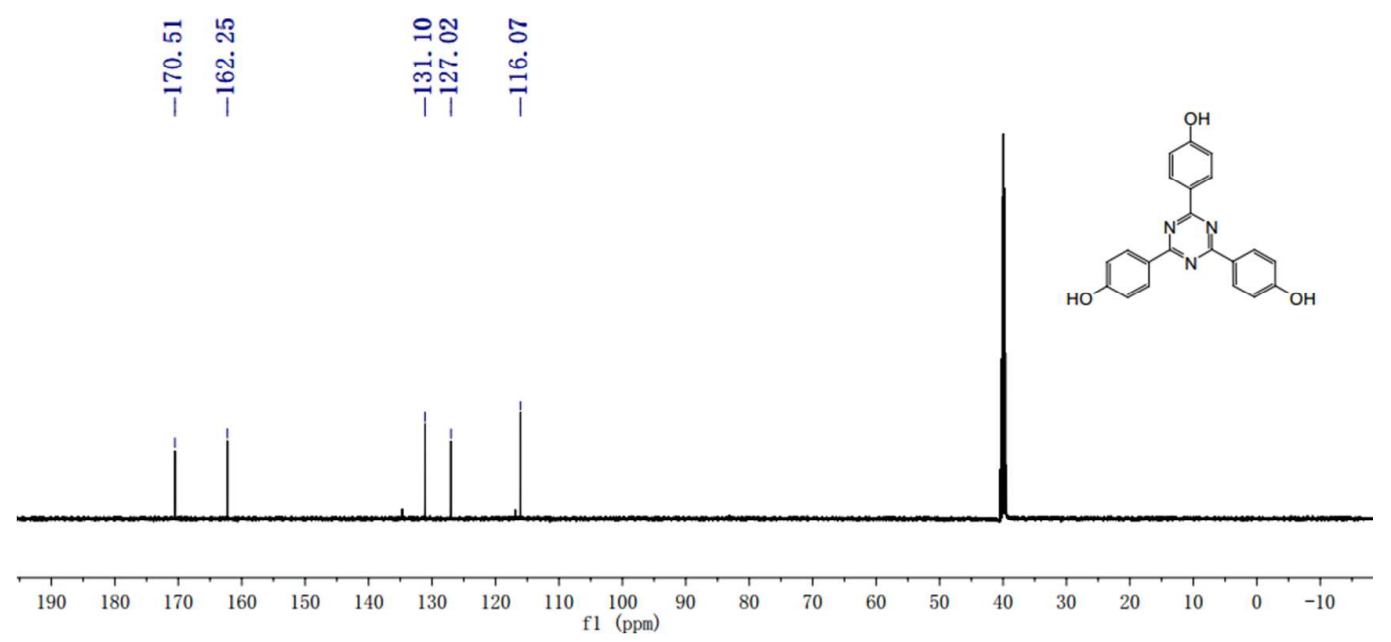

Figure S2. ${ }^{13} \mathrm{C}$ NMR $(126 \mathrm{MHz})$ of 2 in DMSO- $d_{6}$

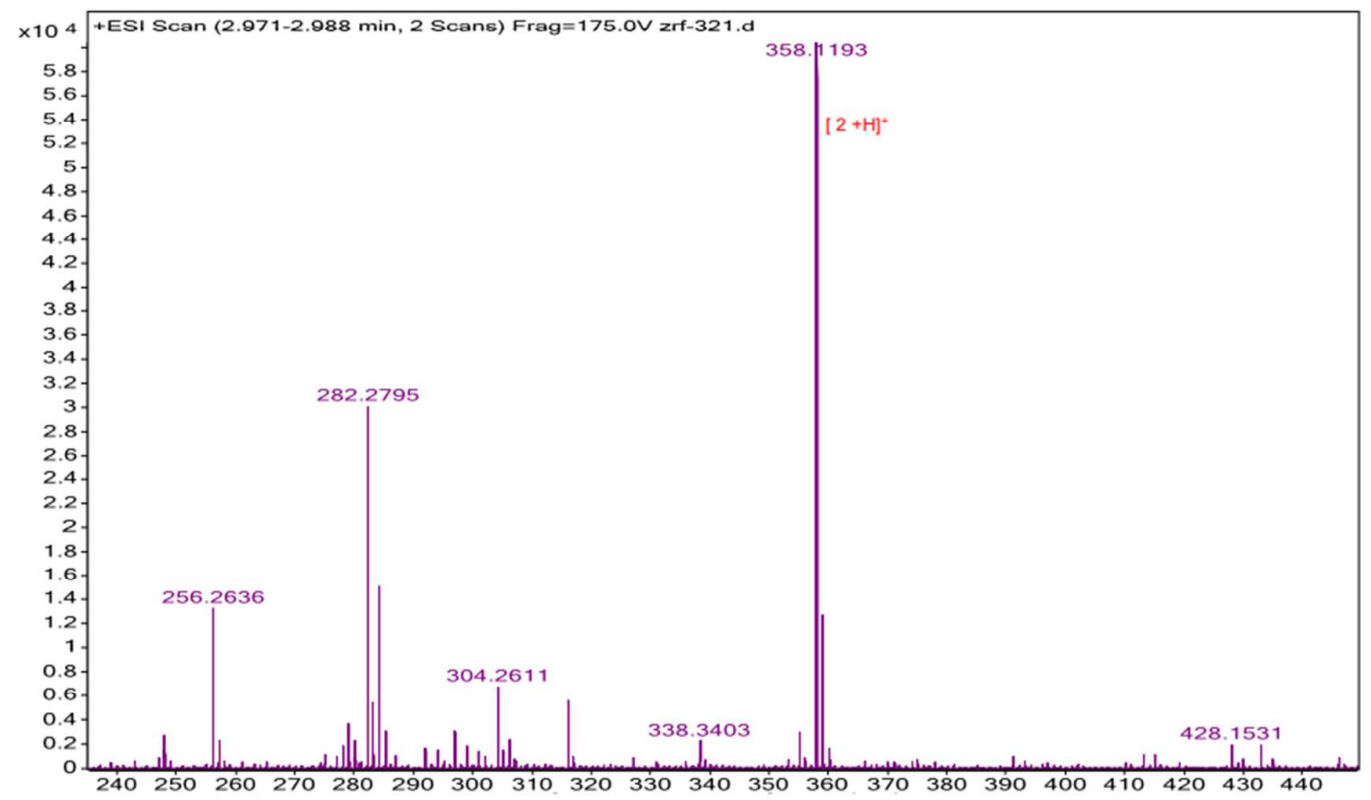

Figure S3. HR-MS of 2. HR-MS: calcd for $\mathrm{C}_{21} \mathrm{H}_{15} \mathrm{~N}_{3} \mathrm{O}_{3} \mathrm{H}^{+}[\mathrm{M}+\mathrm{H}]^{+}$358.1186, found 358.1193 


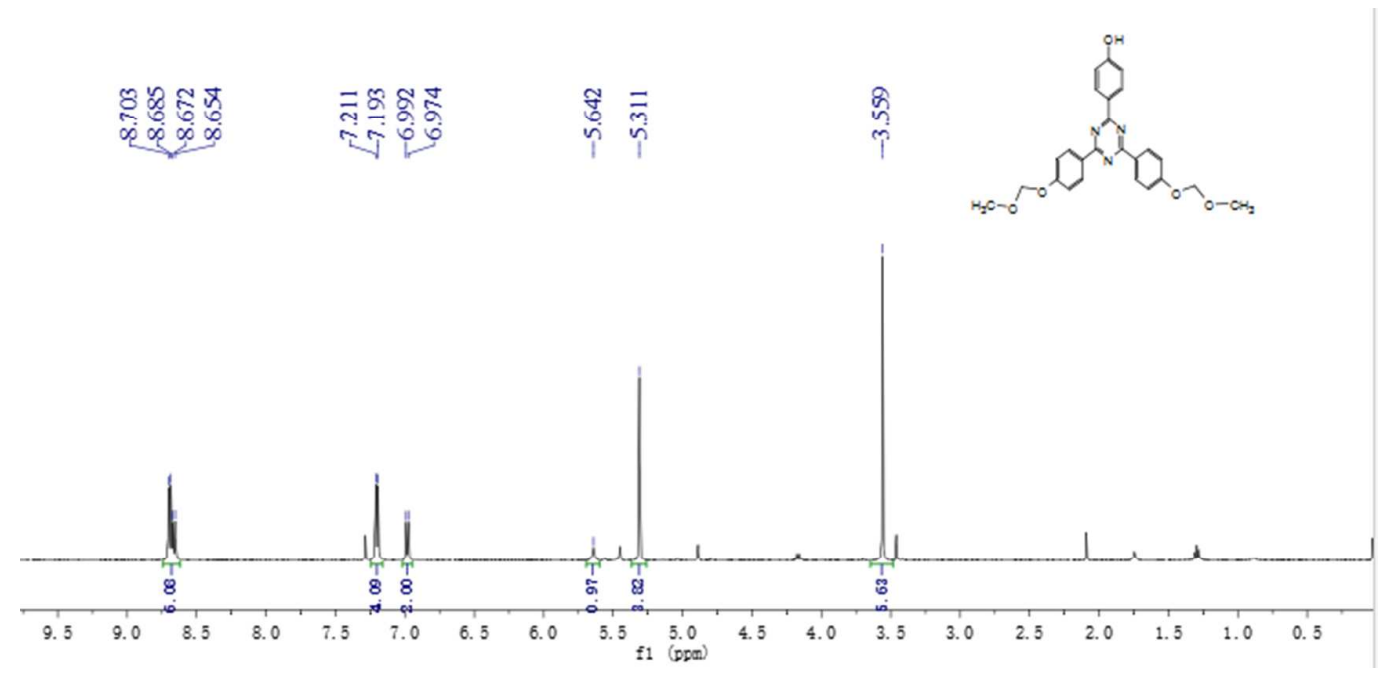

Figure S4. ${ }^{1} \mathrm{H}$ NMR (500 MHz) of 3 in $\mathrm{CDCl}_{3}$

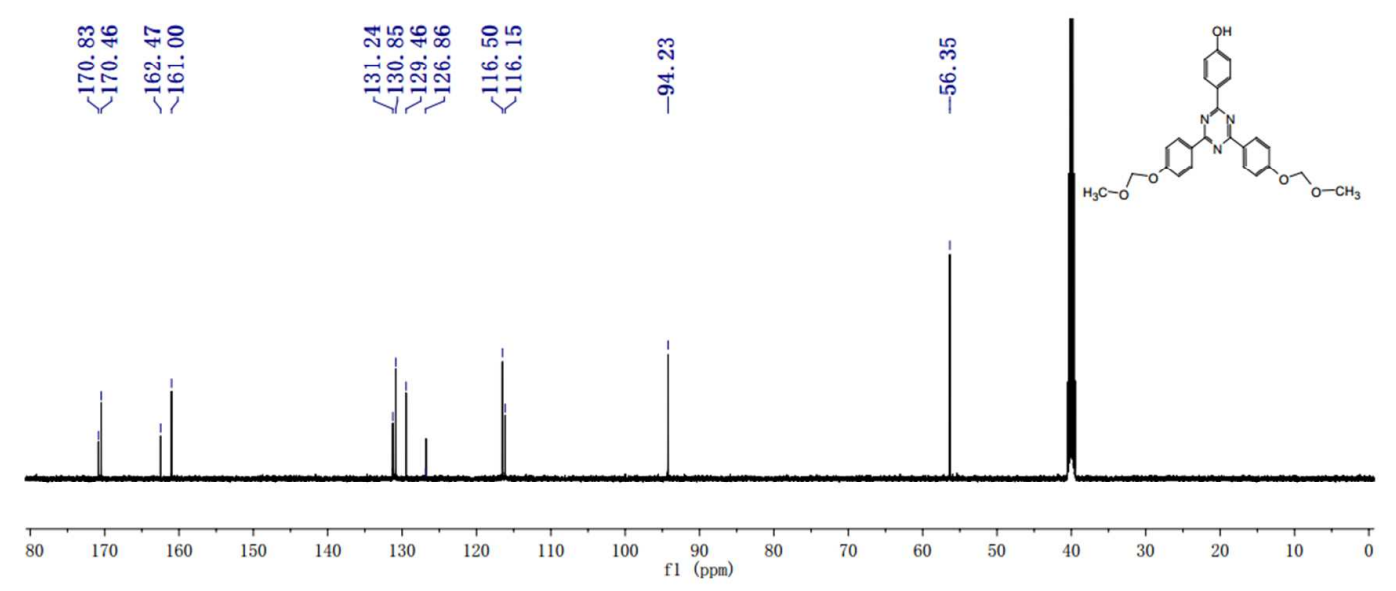

Figure S5. ${ }^{13} \mathrm{C}(126 \mathrm{MHz}) \mathrm{NMR}$ of 3 in DMSO- $d_{6}$ 


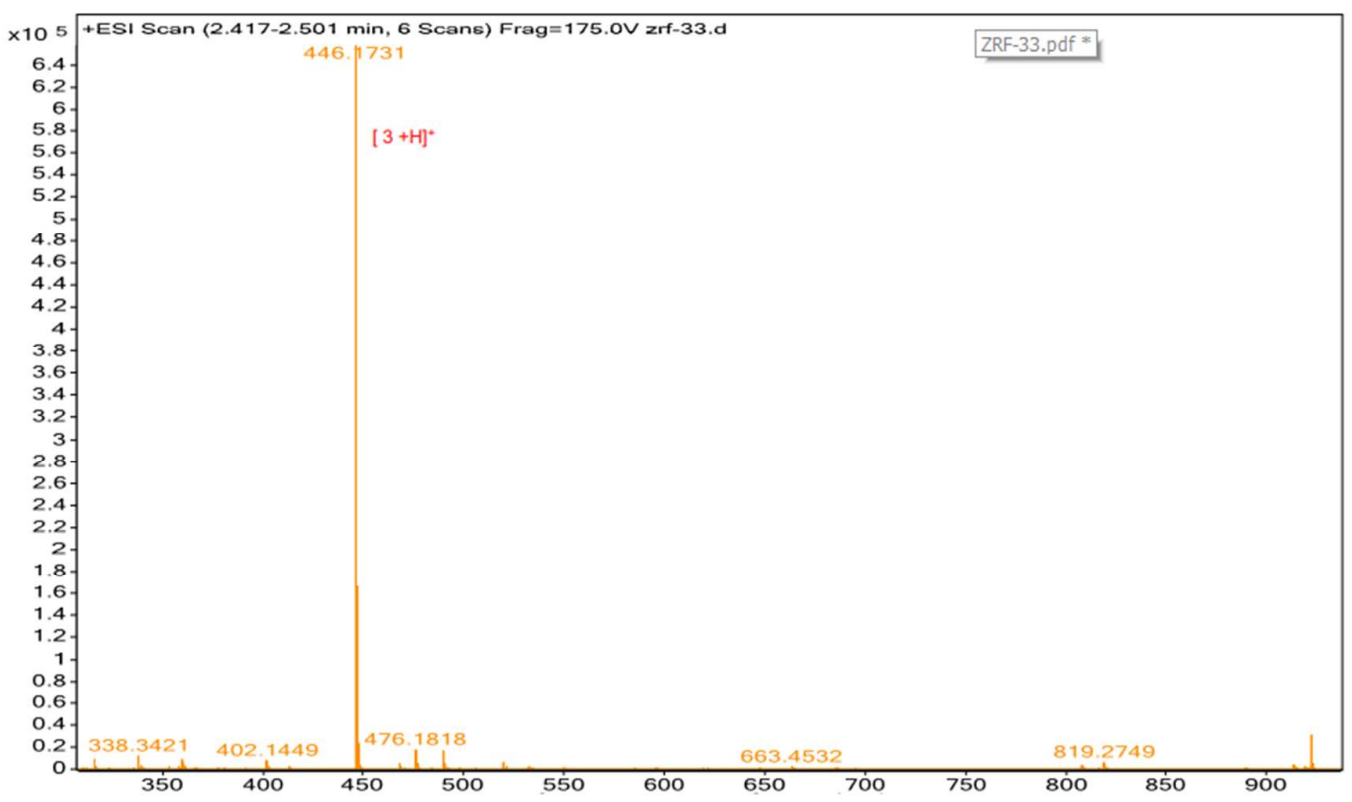

Figure S6. HR-MS of 3. HR-MS calcd for $\mathrm{C}_{25} \mathrm{H}_{23} \mathrm{~N}_{3} \mathrm{O}_{6} \mathrm{H}^{+}[\mathrm{M}+\mathrm{H}]^{+}$446.1710, found 446.1731

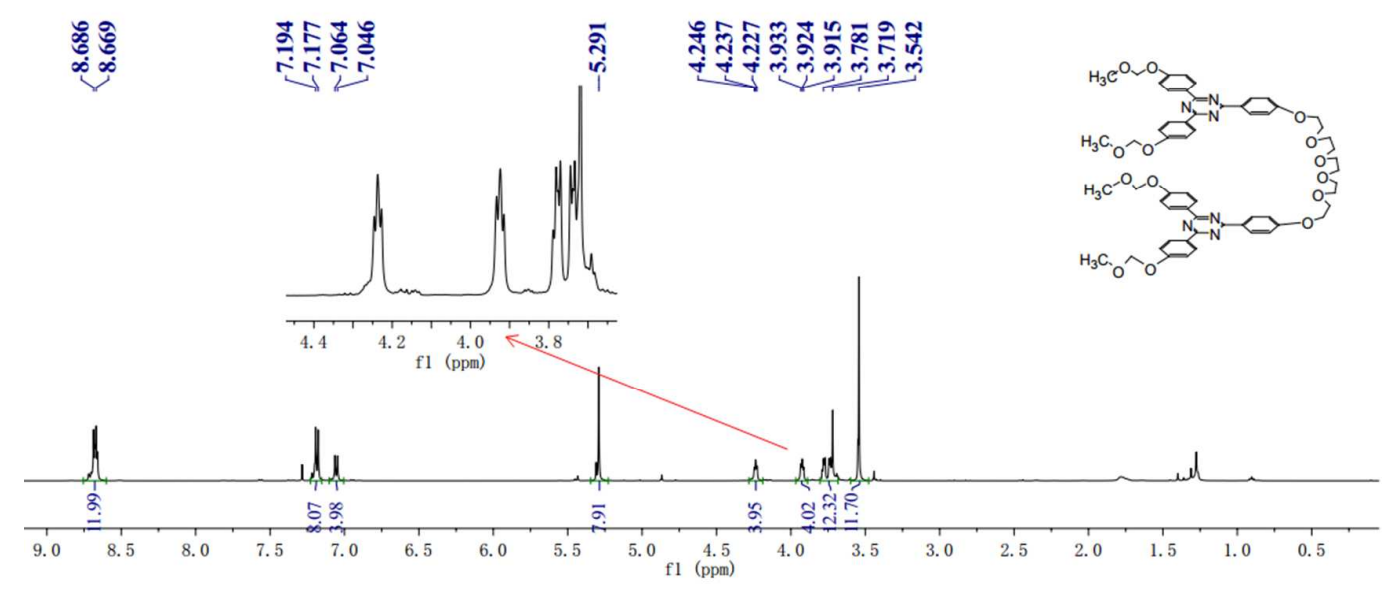

Figure S7. ${ }^{1} \mathrm{H} \mathrm{NMR}(500 \mathrm{MHz})$ of 4 in $\mathrm{CDCl}_{3}$ 


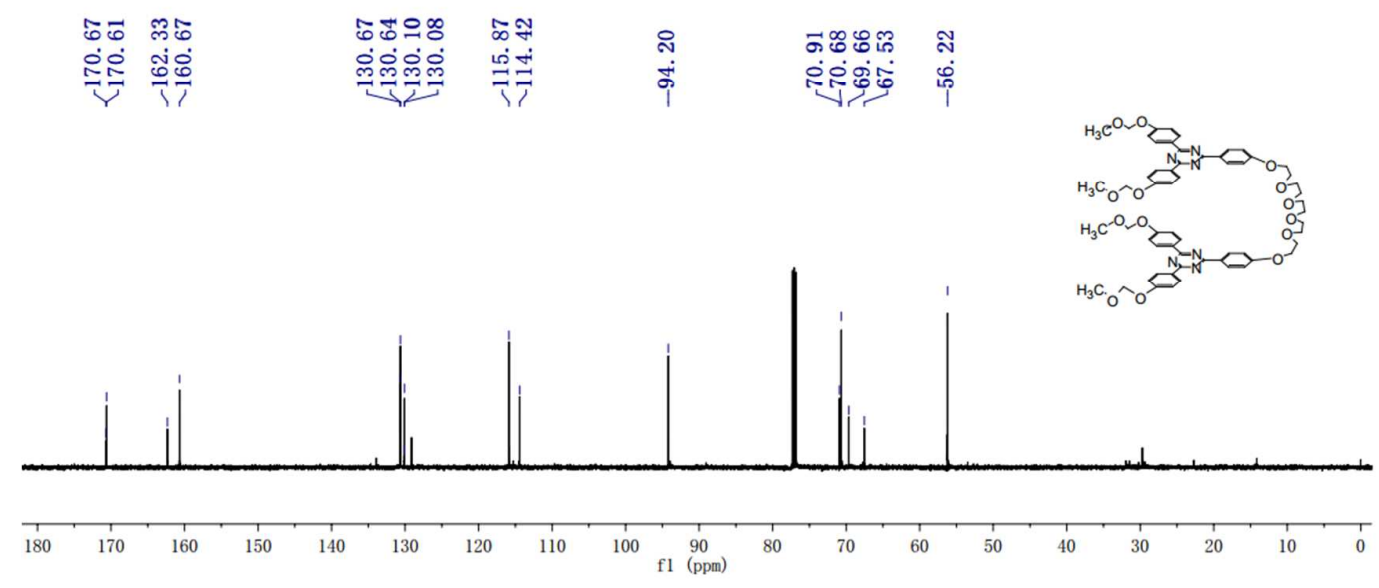

Figure S8. ${ }^{13} \mathrm{C}$ NMR $(126 \mathrm{MHz})$ of 4 in $\mathrm{CDCl}_{3}$

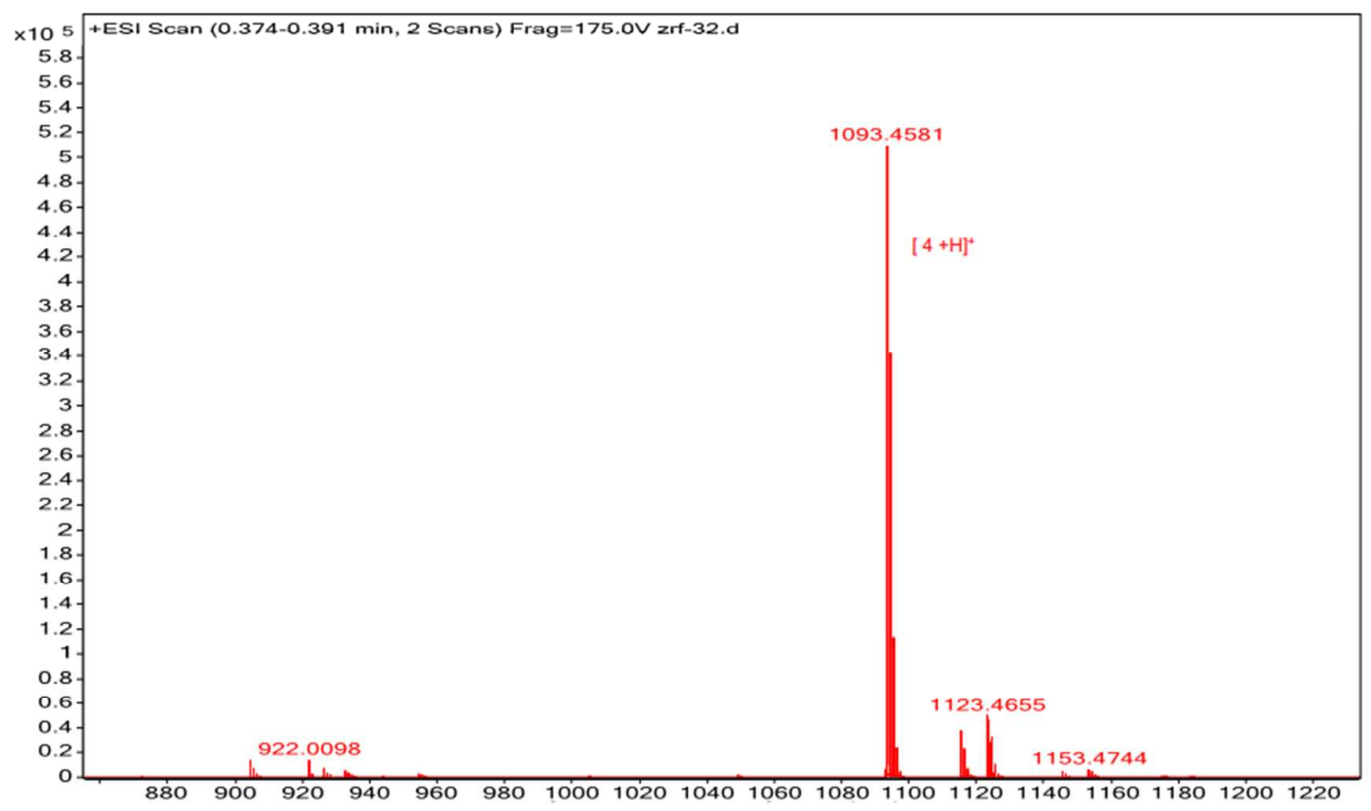

Figure S9. HR-MS of 4. HR-MS calcd for $\mathrm{C}_{60} \mathrm{H}_{64} \mathrm{~N}_{6} \mathrm{O}_{14} \mathrm{H}^{+}[\mathrm{M}+\mathrm{H}]^{+}$1093.4553, found 1093.4581 . 


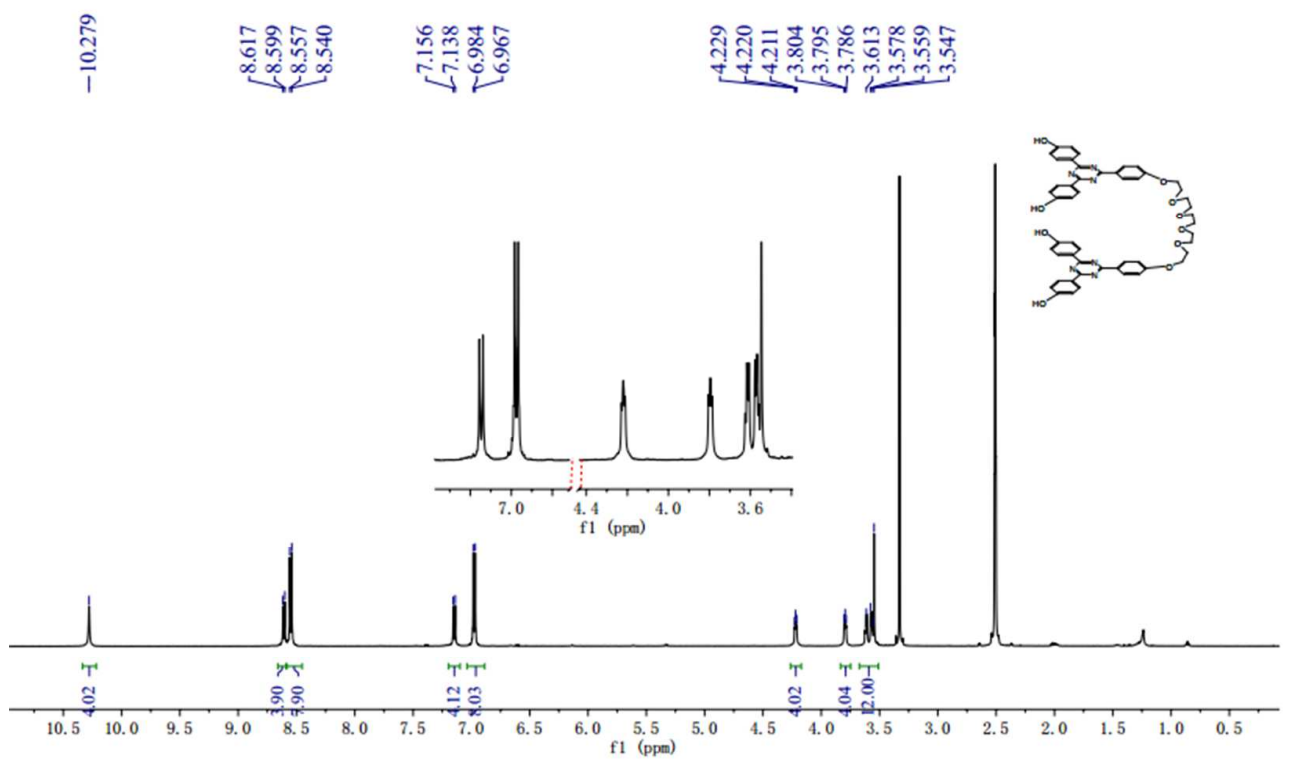

Figure S10. ${ }^{1} \mathrm{H}$ NMR $(500 \mathrm{MHz})$ of 5 in DMSO- $d_{6}$

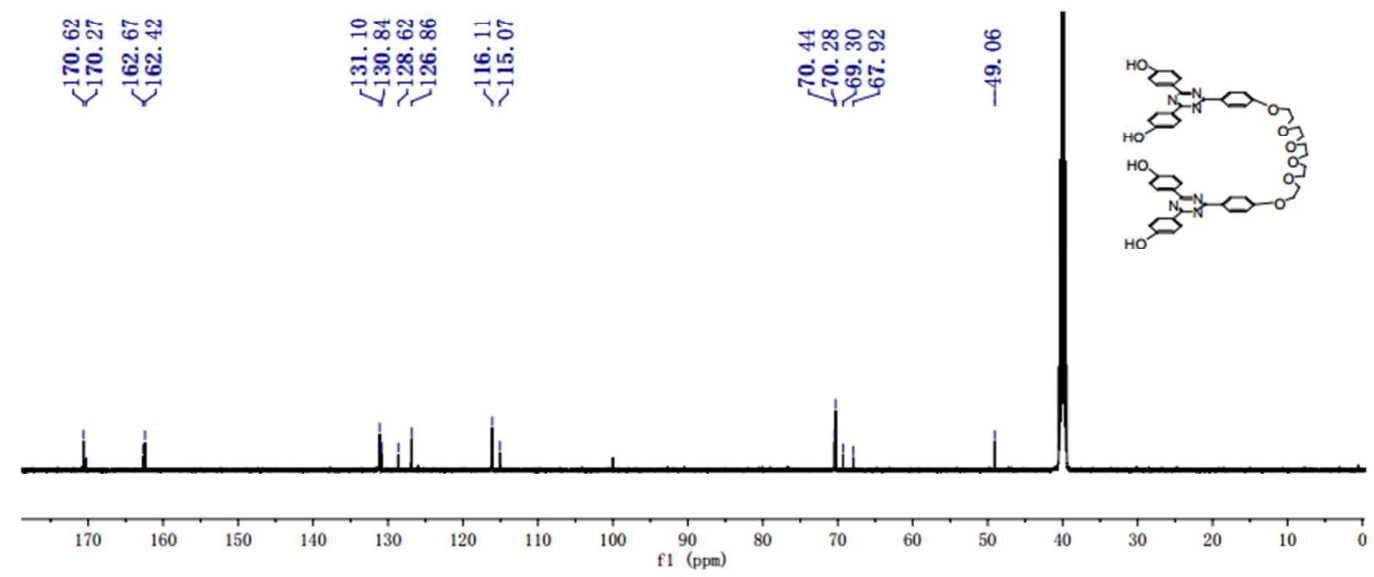

Figure S11. ${ }^{13} \mathrm{C}$ NMR $(126 \mathrm{MHz})$ of 5 in DMSO- $d_{6}$ 


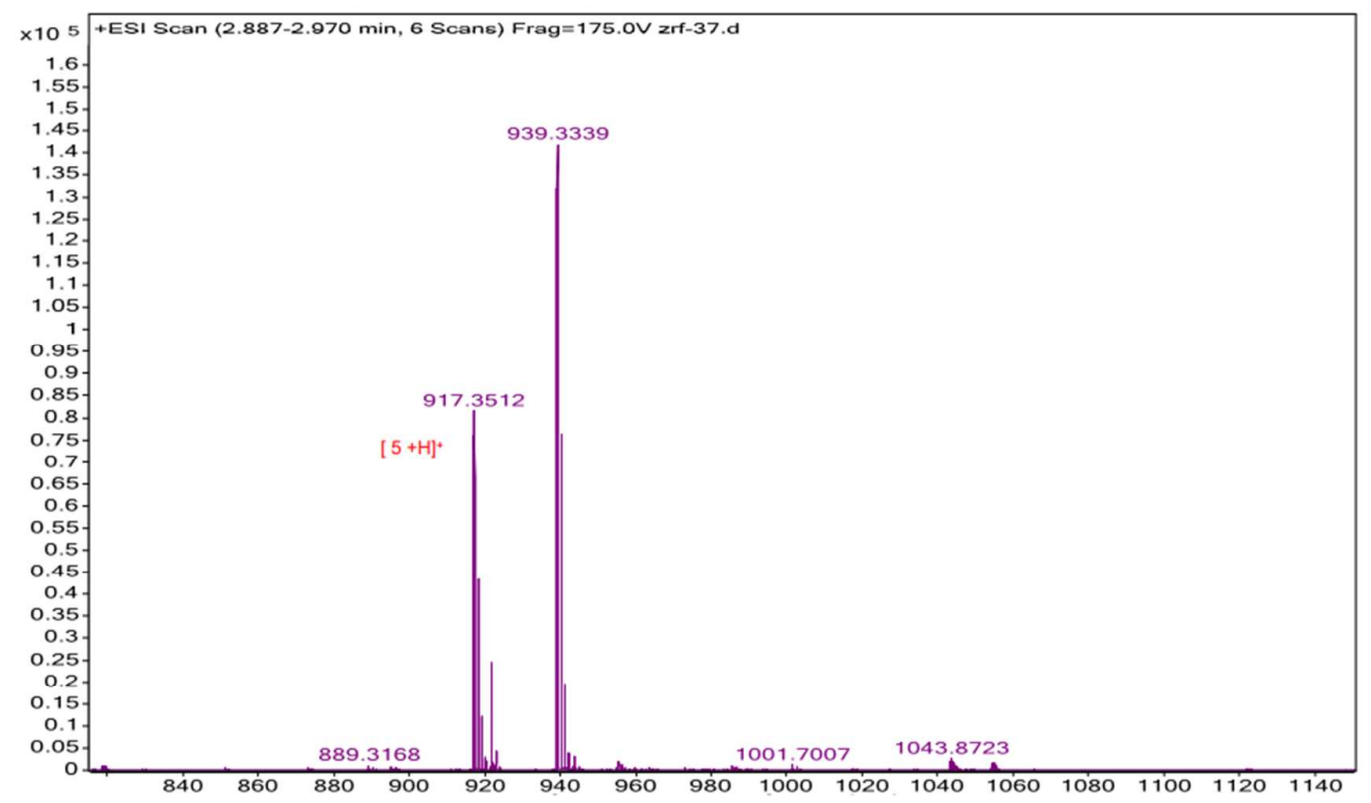

Figure S12. HR-MS of 5. HR-MS calcd for $\mathrm{C}_{52} \mathrm{H}_{48} \mathrm{~N}_{6} \mathrm{O}_{10} \mathrm{H}^{+}[\mathrm{M}+\mathrm{H}]^{+}$917.3505, found 917.3512 .

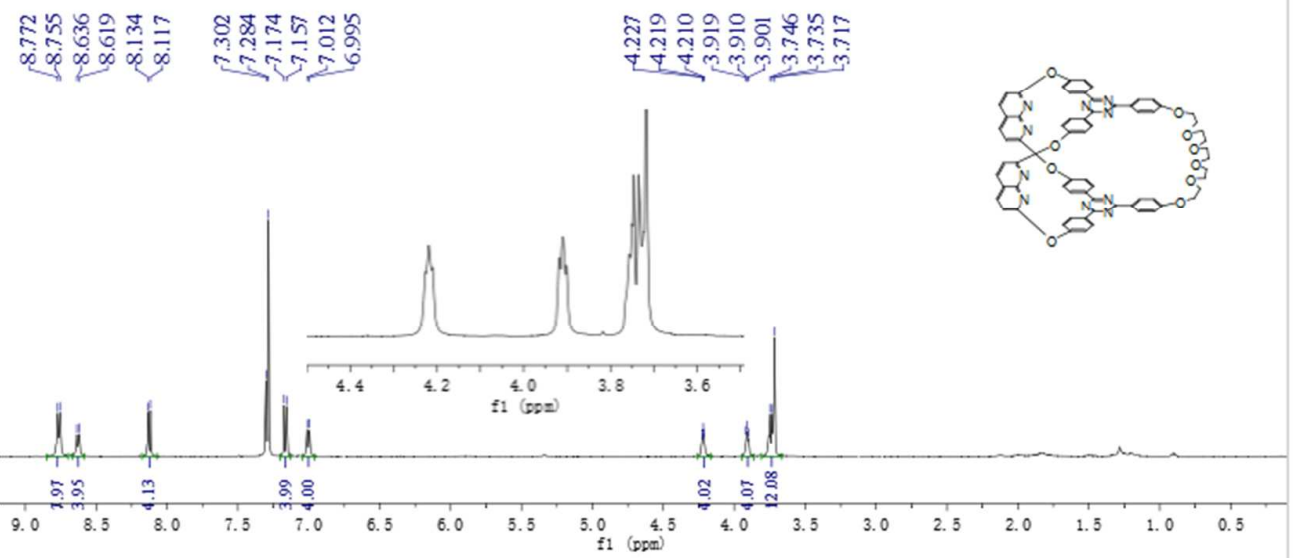

Figure S13. ${ }^{1} \mathrm{H} \mathrm{NMR}(500 \mathrm{MHz})$ of 1 in $\mathrm{CDCl}_{3}$ 


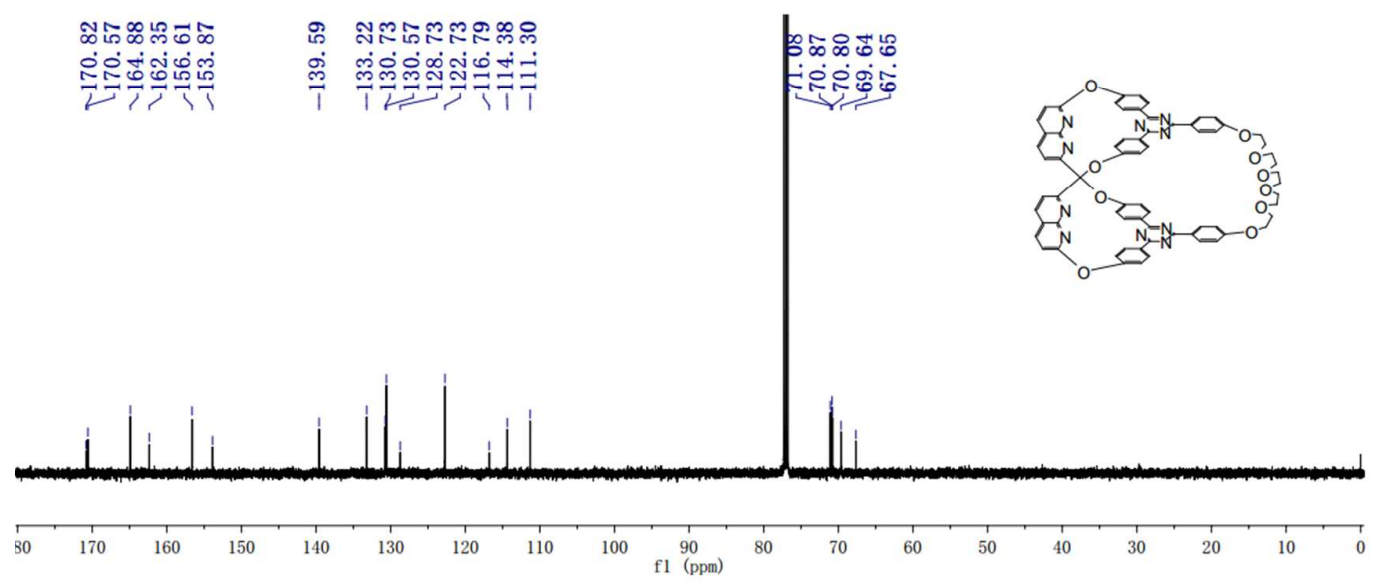

Figure S14. ${ }^{13} \mathrm{C}$ NMR $(126 \mathrm{MHz})$ of 1 in $\mathrm{CDCl}_{3}$ 


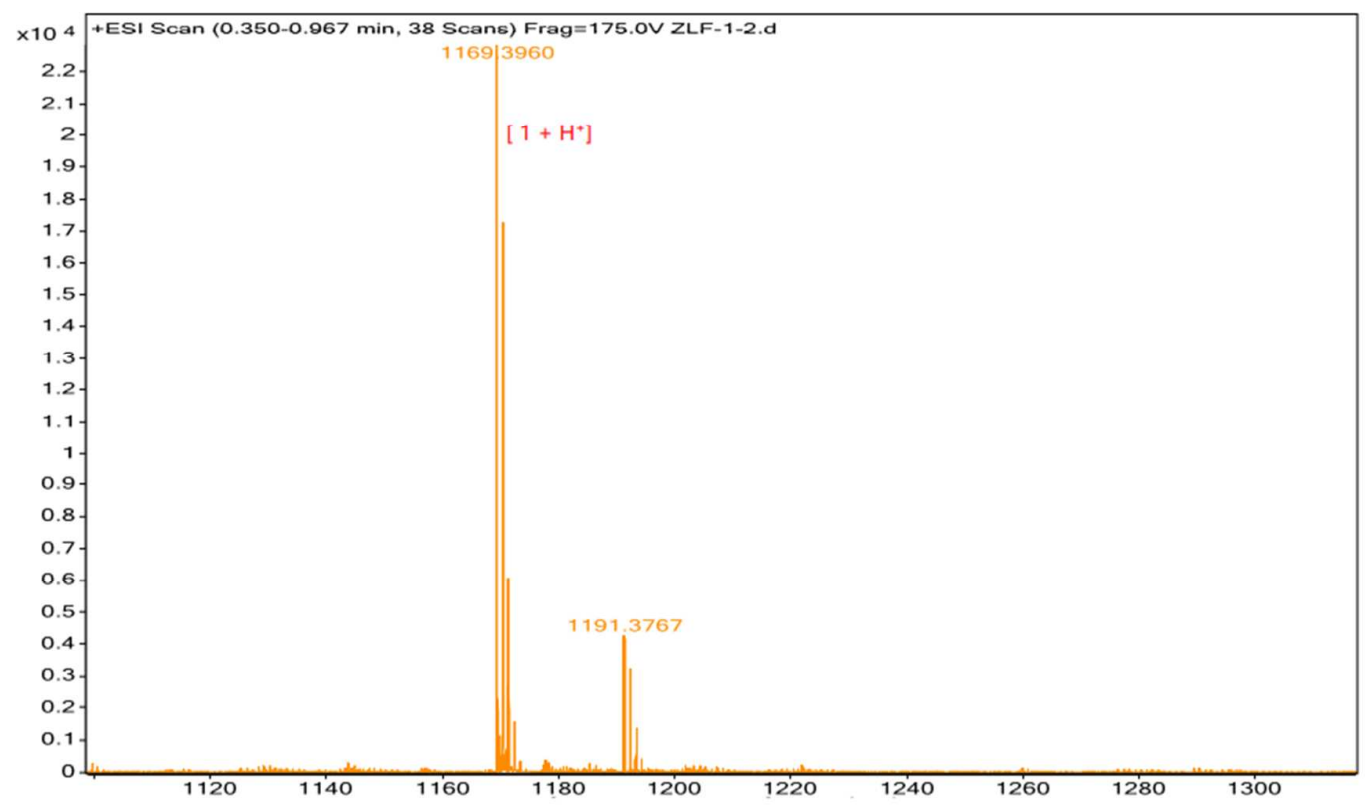

Figure S15. HR-MS of 1. HR-MS calcd for $\mathrm{C}_{68} \mathrm{H}_{52} \mathrm{~N}_{10} \mathrm{O}_{10} \mathrm{H}^{+}[\mathrm{M}+\mathrm{H}]^{+}$1169.3941, found 1169.3960.

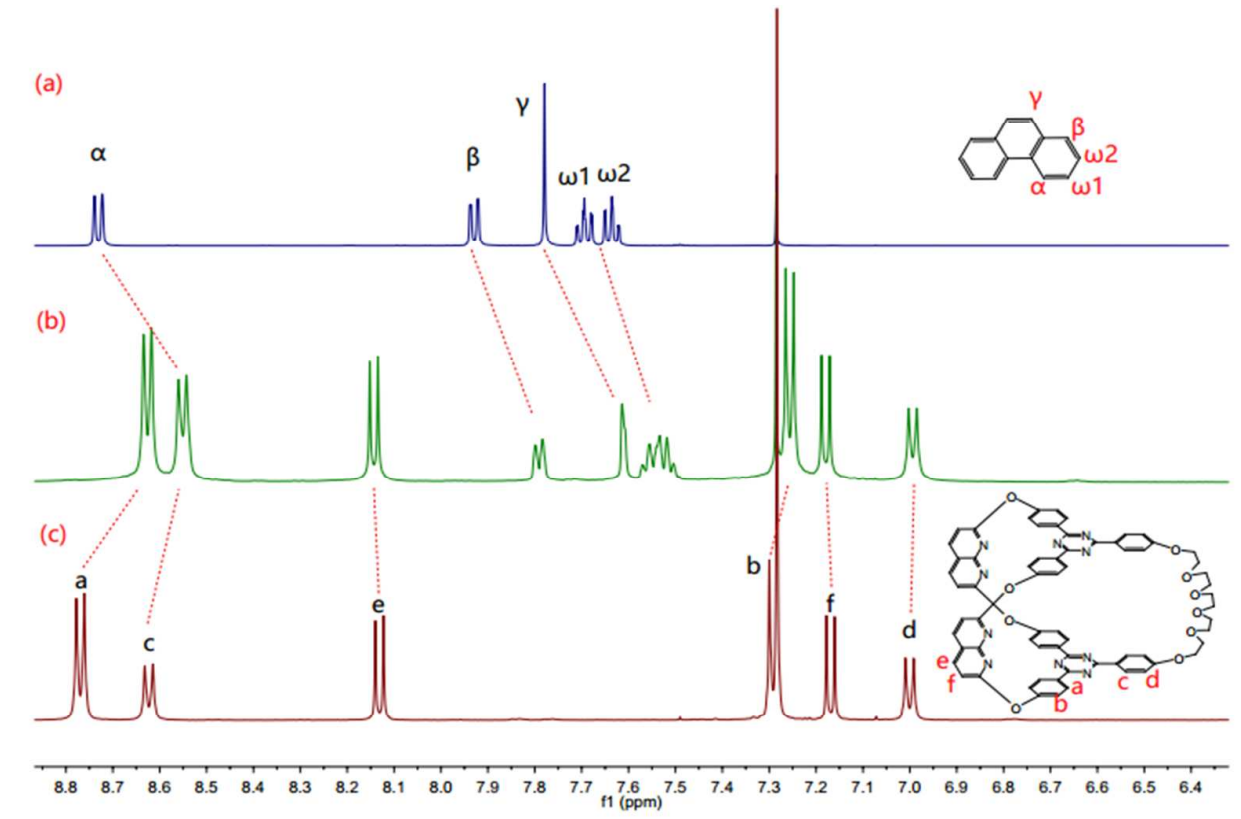


Figure S16. ${ }^{1} \mathrm{H}$ NMR spectra (500 MHz, $\mathrm{CDCl}_{3}, 298 \mathrm{~K}, c=10 \mathrm{mM}$ ) of (a) 6, (b) 1 +6 , (c) 1 .

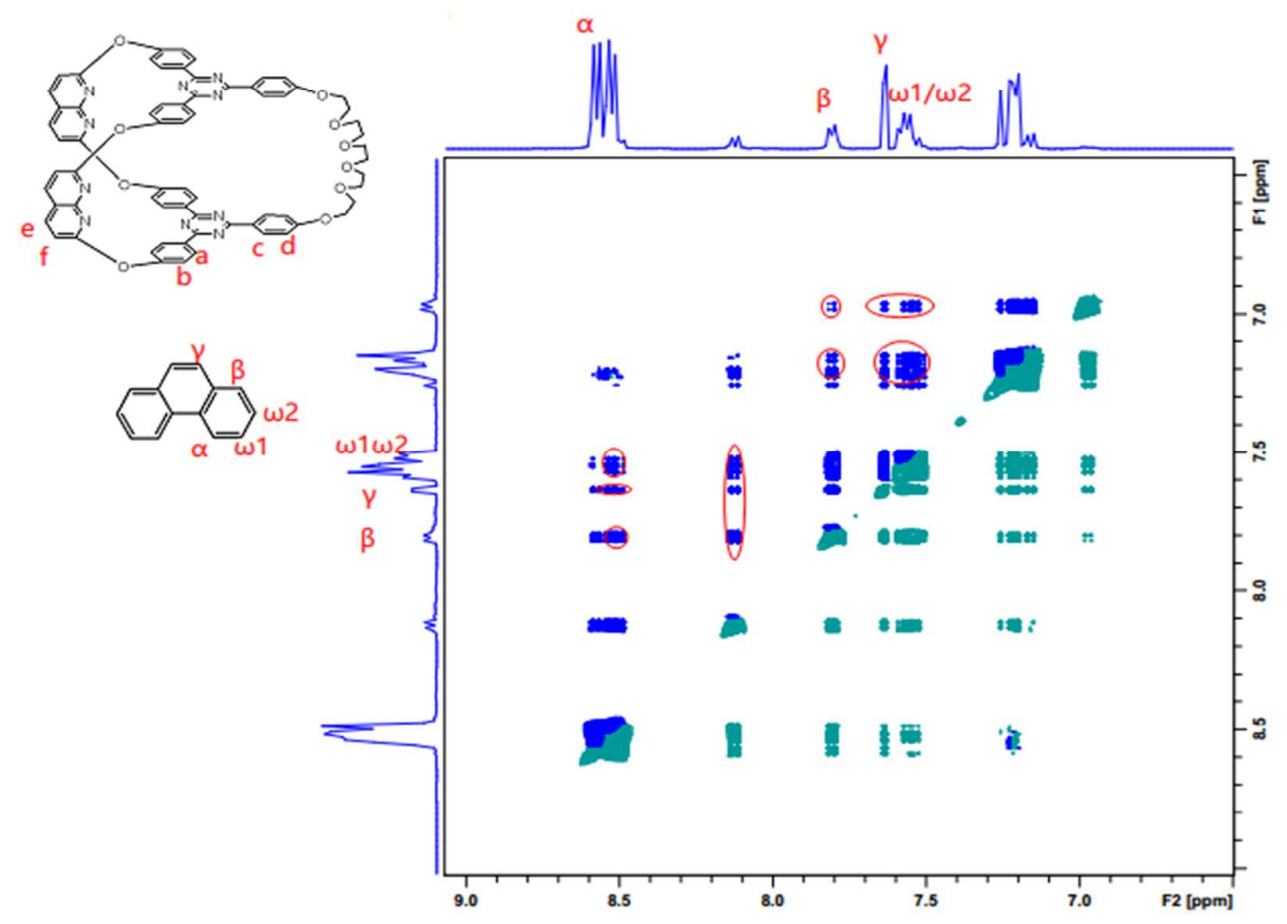

Figure S17. Partial 2D NOESY spectrum of the mixture of $1(10 \mathrm{mM})$ and $\mathbf{6}(10 \mathrm{mM})$ in $\mathrm{CDCl}_{3}(400 \mathrm{MHz}, 298 \mathrm{~K})$.

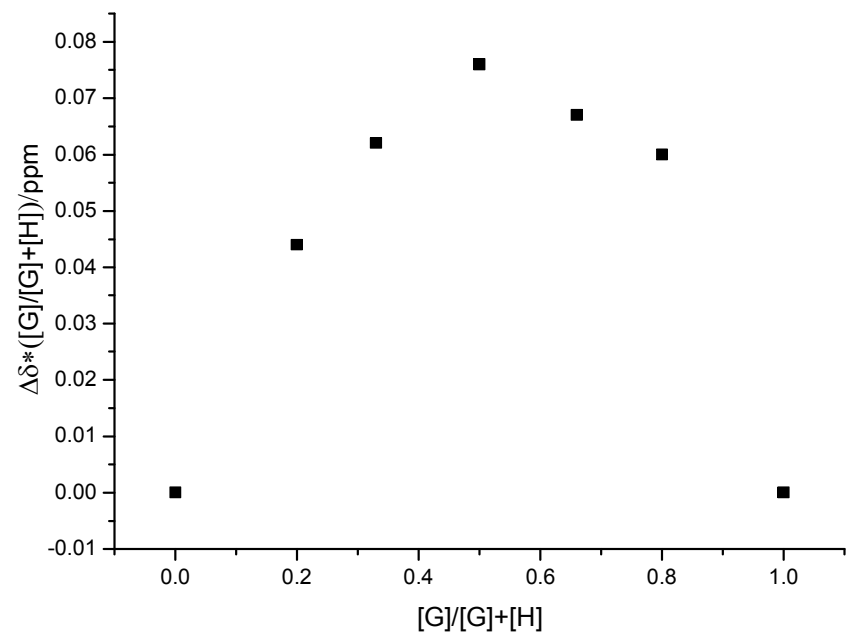

Figure S18. Job plot showing the 1:1 stoichiometry of the complex between $\mathbf{1}$ and $\mathbf{6}$ in $\mathrm{CDCl}_{3}$ by plotting the $\Delta \delta$ in chemical shift of $\mathbf{1}^{\prime} \mathrm{H}_{\mathrm{a}}$ proton signals observed by ${ }^{1} \mathrm{H}$ NMR spectra against the molar fraction of complex ([host] + [guest] $=20 \mathrm{mM})$. 
To determine the stoichiometry and association constant between host $\mathbf{1}$ and guests $\mathbf{G}$, ${ }^{1} \mathrm{H}$ NMR titration was carried out with solutions which had a constant concentration of $1(10 \mathrm{mM})$ and varying concentrations of guests $\mathbf{G}$. By a non-linear curve-fitting method, the association constants between the guests $\mathbf{G}$ and host $\mathbf{1}$ were calculated. The non-linear curve-fitting was based on the equation ${ }^{[1]}$

$\Delta \delta=\left(\Delta \delta_{\infty} /[\mathbf{1}]_{0}\right)\left(0.5[\mathbf{G}]_{0}+0.5\left([\mathbf{1}]_{0}+1 / K a\right)-\left(0.5\left([\mathbf{G}]_{0}{ }^{2}+\left(2[\mathbf{G}]_{0}\left(1 / K a-[\mathbf{1}]_{0}\right)\right)+(1 / K a+\right.\right.\right.$ $\left.\left.\left.\left.[1]_{0}\right)^{2}\right)^{0.5}\right)\right)$

Where $\Delta \delta$ is the chemical shift change of $\mathrm{H}_{\mathrm{a}}$ on $\mathbf{1}$ at $[\mathbf{G}]_{0}, \Delta \delta_{\infty}$ the chemical shift change of $\mathrm{H}_{\mathrm{a}}$ when $\mathbf{1}$ is completely complexed, [1 $]_{0}$ the fixed initial concentration of $\mathbf{1}$, and $[\mathrm{G}]_{0}$ the varying concentrations of guest.

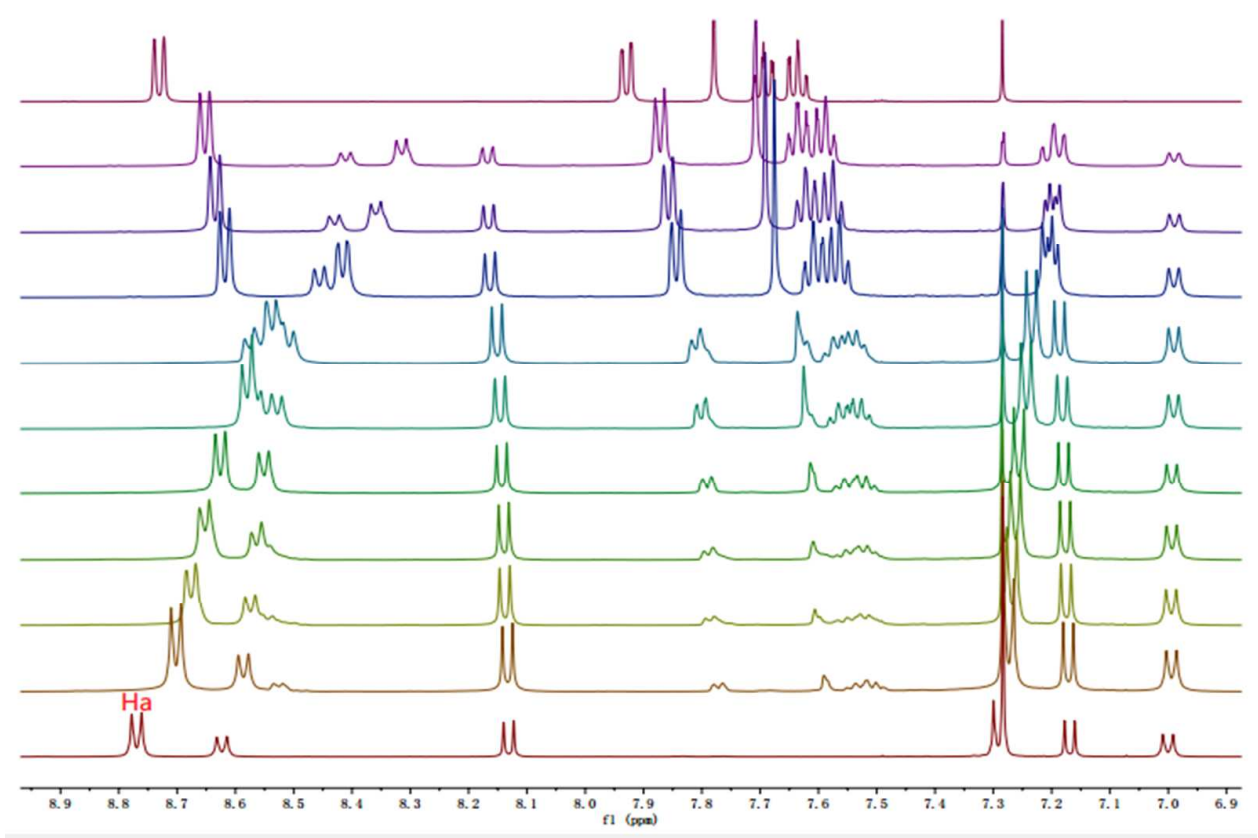

Figure S19. ${ }^{1} \mathrm{H}$ NMR spectra $\left(\mathrm{CDCl}_{3}, 500 \mathrm{MHz}, 298 \mathrm{~K}\right)$ of $\mathbf{1}$ at a concentration of $10 \mathrm{mM}$ upon addition of $\mathbf{6}$. From bottom to top, the concentrations of $\mathbf{6}$ were $0.0,4.0$, $6.0,8.0,10,15,20,40,60$, and $80 \mathrm{mM}$, respectively. 


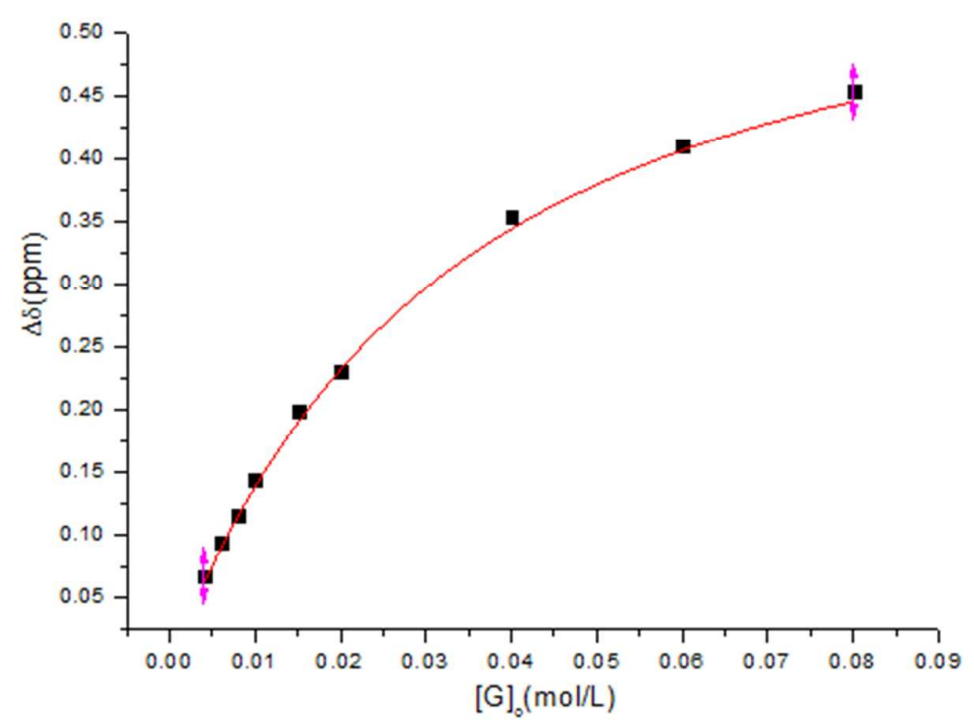

Figure S20. The non-linear curve-fitting (NMR titrations, $\Delta \delta$ of $\mathrm{H}_{\mathrm{a}}$ ) for the complexation of $1(10.0 \mathrm{mM})$ with $\mathbf{6}$ in $\mathrm{CDCl}_{3}$ at $298 \mathrm{~K}$. The concentrations of $\mathbf{6}$ were $0.0,4.0,6.0,8.0,10,15,20,40,60$, and $80 \mathrm{mM}$, respectively. The $K_{\mathrm{a}}$ value for complex $6 \subset 1$ in $\mathrm{CDCl}_{3}$ at $298 \mathrm{~K}$ is determined to be $(3.9 \pm 0.3) \times 10^{1} \mathrm{M}^{-1}$.

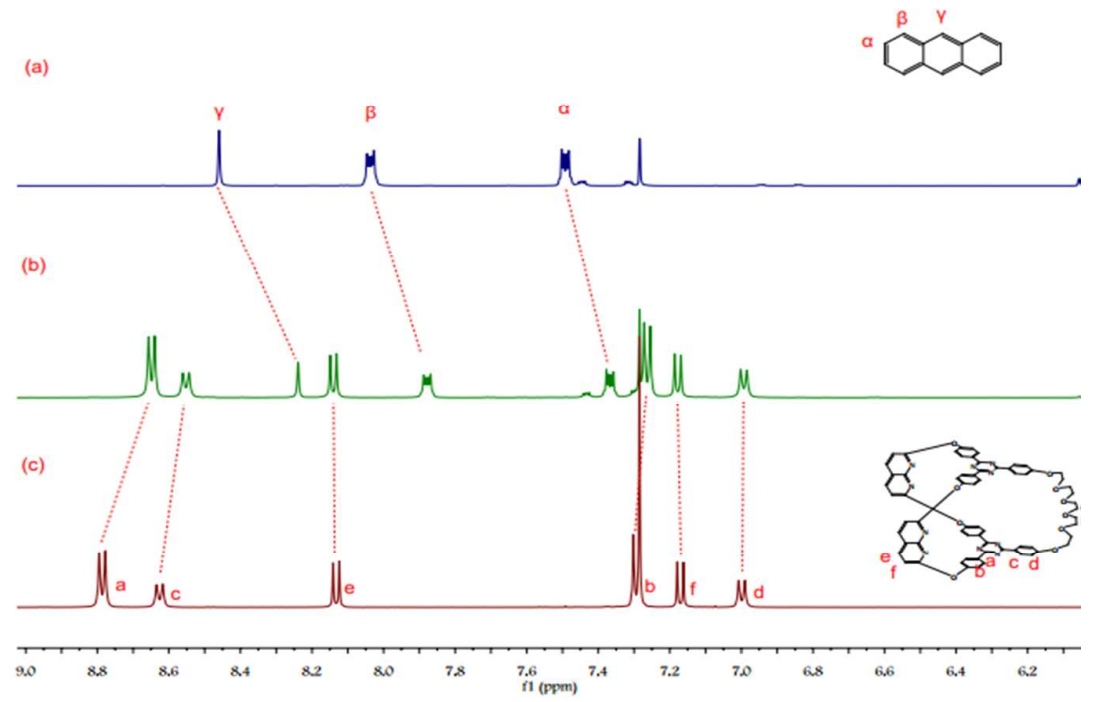

Figure S21. ${ }^{1} \mathrm{H}$ NMR spectra $\left(500 \mathrm{MHz}, \mathrm{CDCl}_{3}, 298 \mathrm{~K}, c=10 \mathrm{mM}\right)$ of (a) 7, (b) $\mathbf{1}+$ 7 , and (c) 1 . 


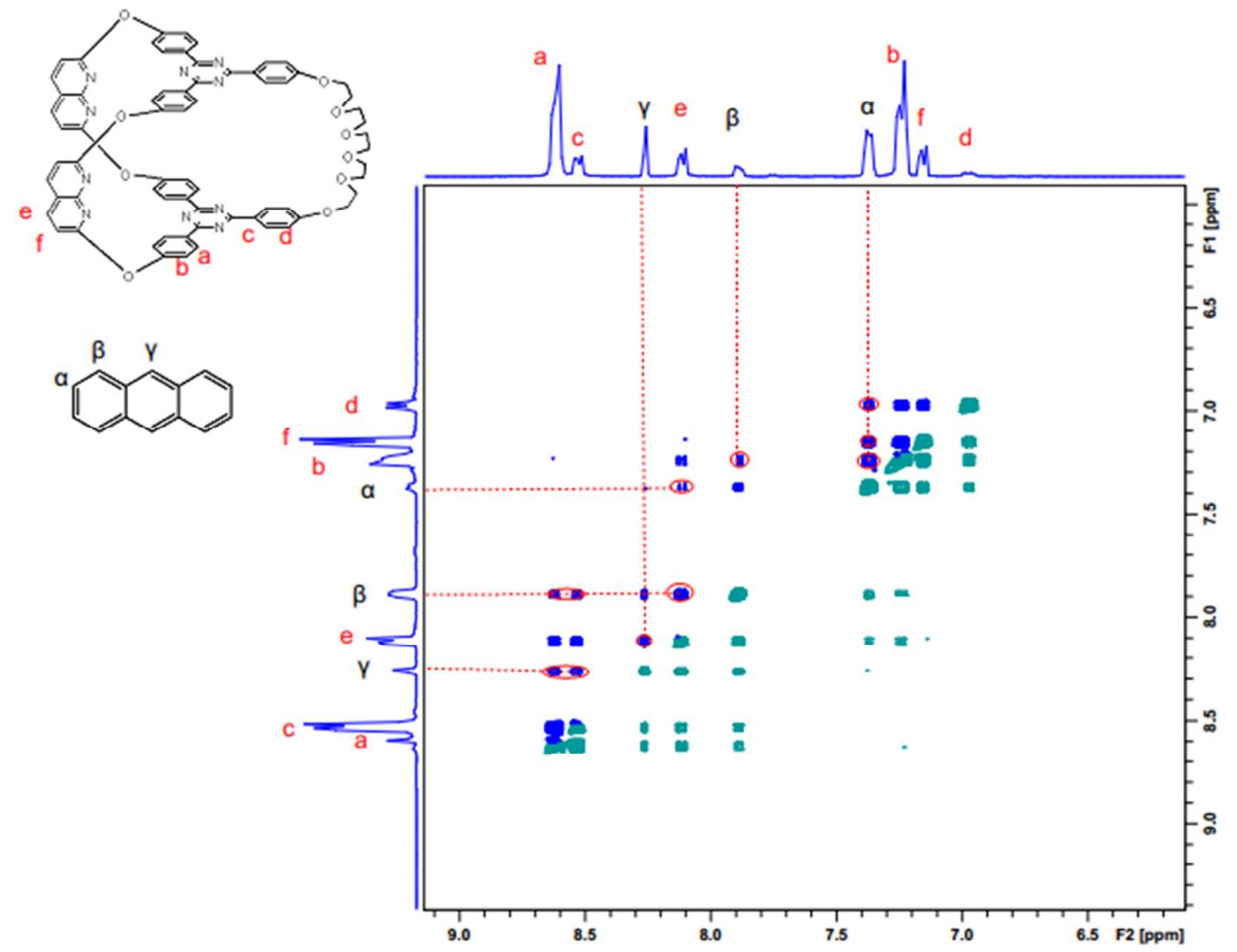

Figure S22. Partial 2D NOESY spectrum $\left(400 \mathrm{MHz}, \mathrm{CDCl}_{3}\right)$ of an equal molar mixture of $1(10 \mathrm{mM})$ and $7(10 \mathrm{mM})$ in $\mathrm{CDCl}_{3}$.

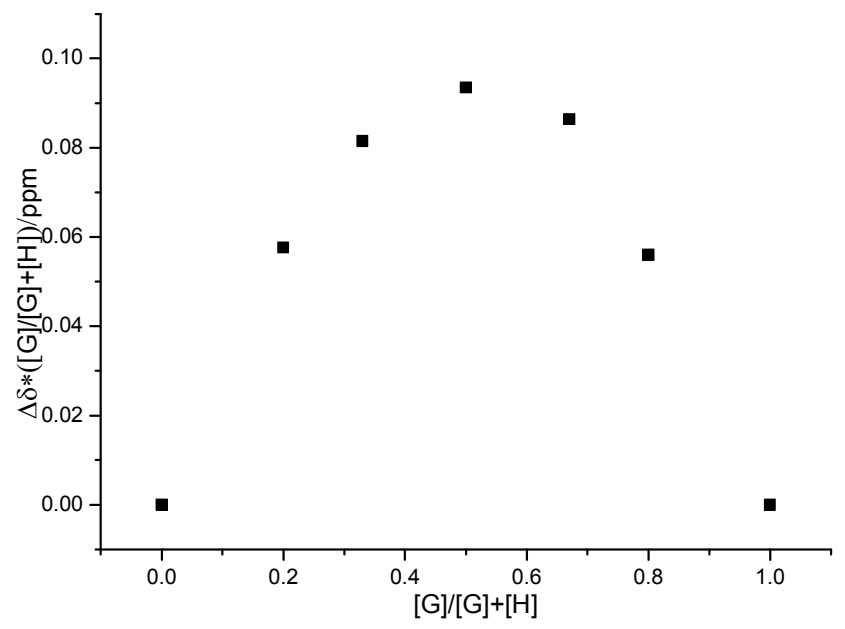

Figure S23. Job plot showing the 1:1 stoichiometry of the complex between 1 and 7 in $\mathrm{CDCl}_{3}$ by plotting the $\Delta \delta$ in chemical shift of 1 's $\mathrm{H}_{\mathrm{a}}$ proton signals observed by ${ }^{1} \mathrm{H}$ NMR spectroscopy against the molar fraction of complex ([host] + [guest] $=20 \mathrm{mM})$. 


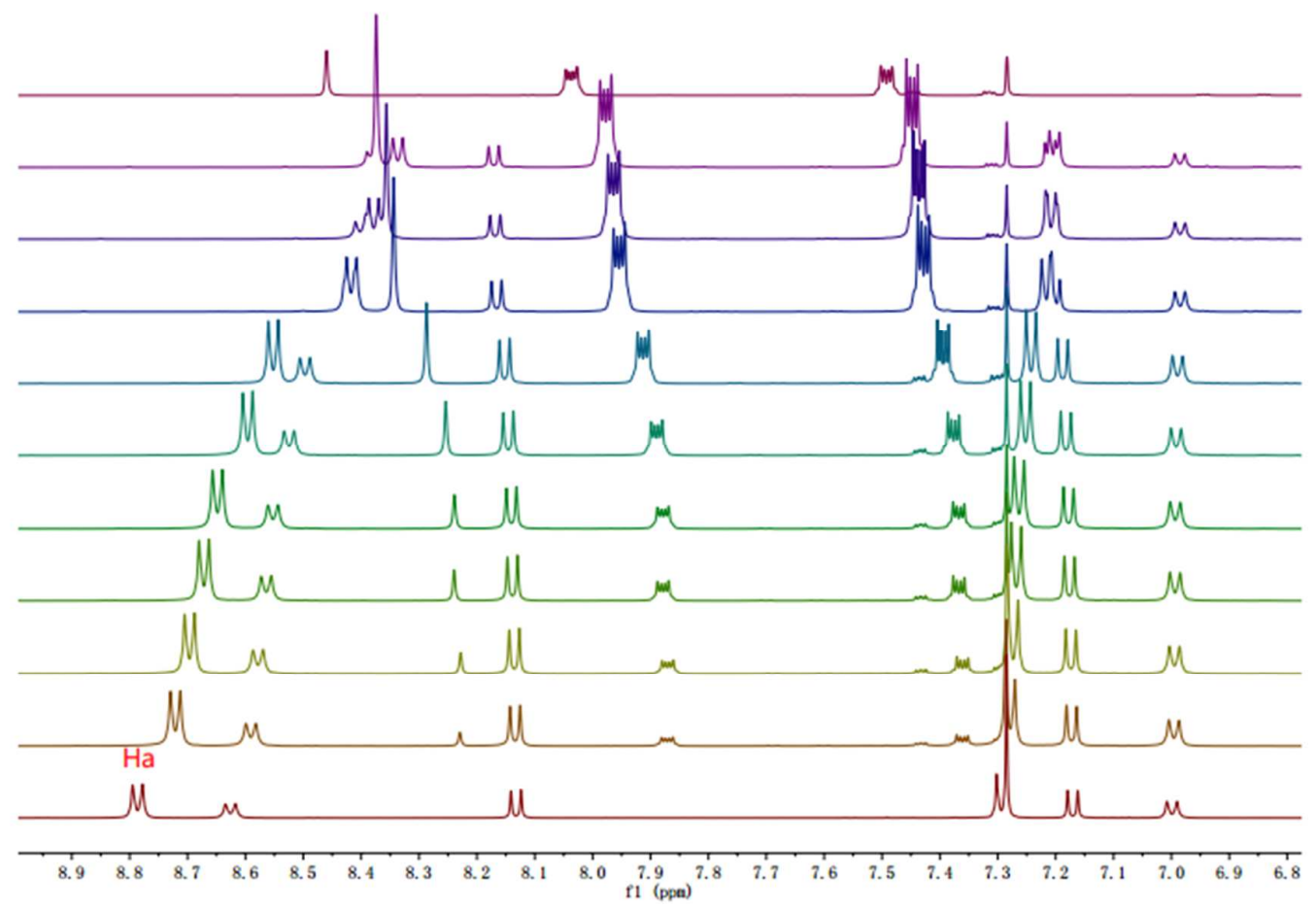

Figure S24. ${ }^{1} \mathrm{H}$ NMR spectra $\left(\mathrm{CDCl}_{3}, 500 \mathrm{MHz}, 298 \mathrm{~K}\right)$ of $\mathbf{1}$ at a concentration of 10 $\mathrm{mM}$ upon addition of 7. From bottom to top, the concentrations of 7 were $0.0,4.0,6.0$, $8.0,10,15,20,40,60$, and $80 \mathrm{mM}$, respectively.

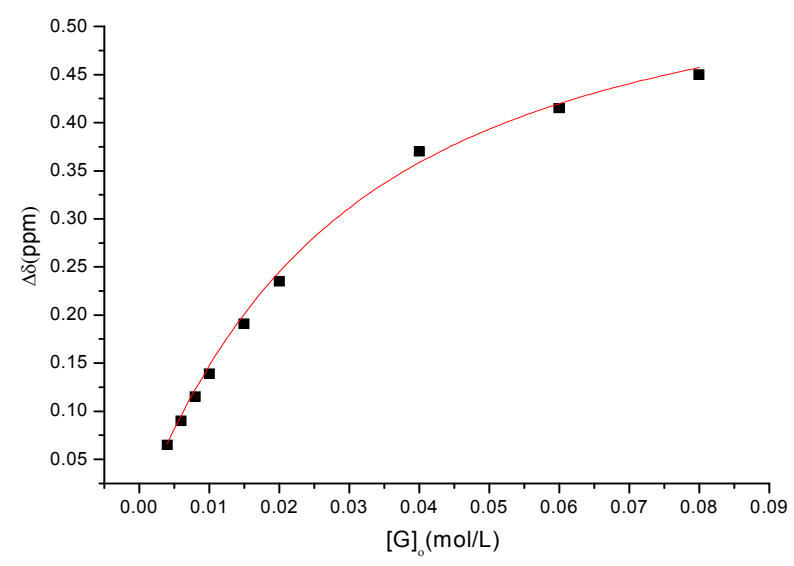

Figure S25. The non-linear curve-fitting (NMR titrations, $\Delta \delta$ of $\mathrm{H}_{\mathrm{a}}$ ) for the complexation of $\mathbf{1}(10.0 \mathrm{mM})$ with 7 in $\mathrm{CDCl}_{3}$ at $298 \mathrm{~K}$. The concentration of 7 were $0.0,4.0,6.0,8.0,10,15,20,40,60$, and $80 \mathrm{mM}$, respectively. The $K_{\mathrm{a}}$ value for complex $7 \subset 1$ in $\mathrm{CDCl}_{3}$ at $298 \mathrm{~K}$ was determined to be $(4.2 \pm 0.4) \times 10^{1} \mathrm{M}^{-1}$. 

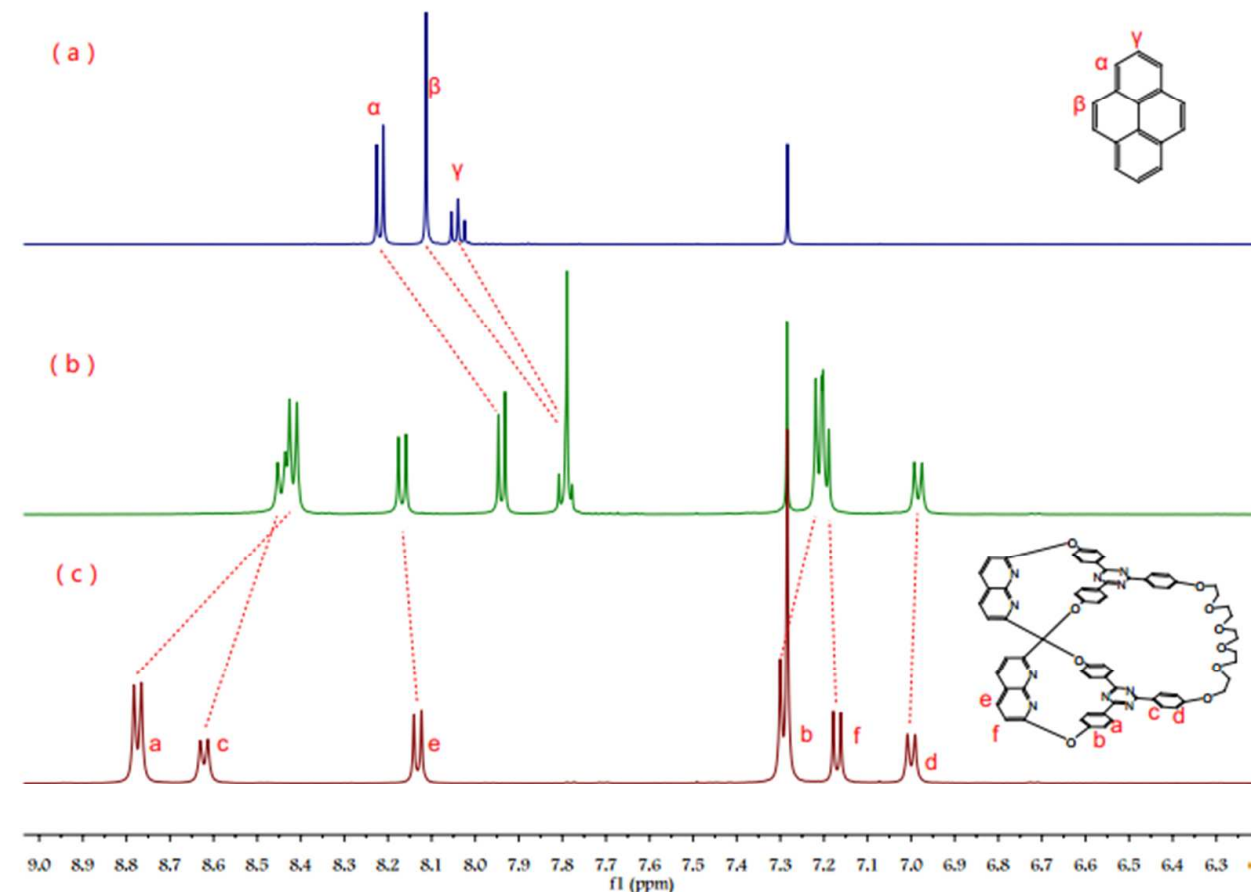

Figure S26. ${ }^{1} \mathrm{H}$ NMR spectra (500 MHz, $\left.\mathrm{CDCl}_{3}, 298 \mathrm{~K}, c=10 \mathrm{mM}\right)$ of: (a) 8, (b) $\mathbf{1}+$ 8, (c) 1 .

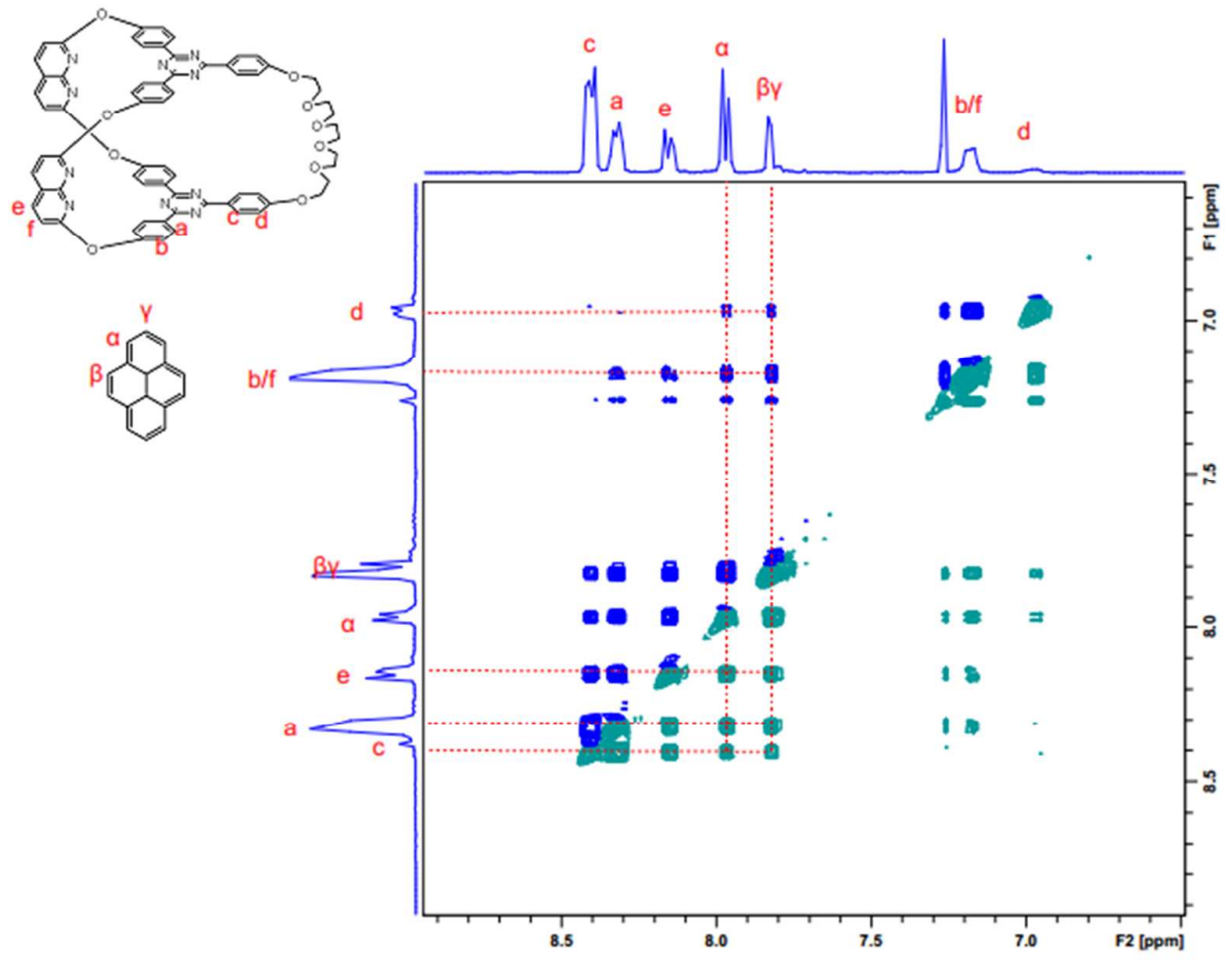

Figure S27. Partial 2D NOESY spectrum of the mixture of $1(10 \mathrm{mM})$ and $\mathbf{8}(10$ $\mathrm{mM})$ in $\mathrm{CDCl}_{3}(400 \mathrm{MHz}, 298 \mathrm{~K})$. 


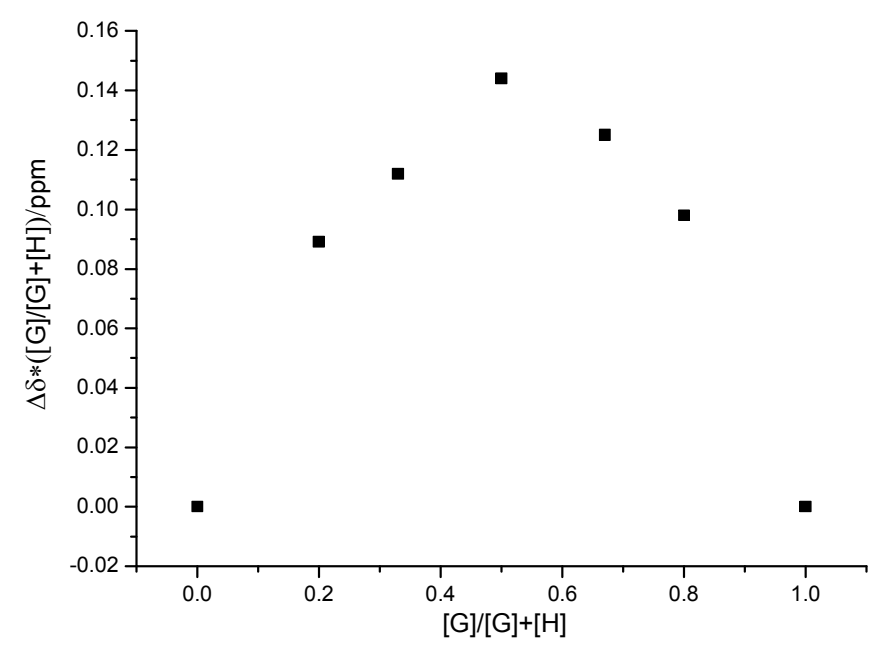

Figure S28. Job plot showing the 1:1 stoichiometry of the complex between $\mathbf{1}$ and $\mathbf{8}$ in $\mathrm{CDCl}_{3}$ by plotting the $\Delta \delta$ in chemical shift of 1 's $\mathrm{H}_{\mathrm{a}}$ proton signals observed by ${ }^{1} \mathrm{H}$ NMR spectrum against the molar fraction of complex ([host] + [guest $]=20 \mathrm{mM})$.

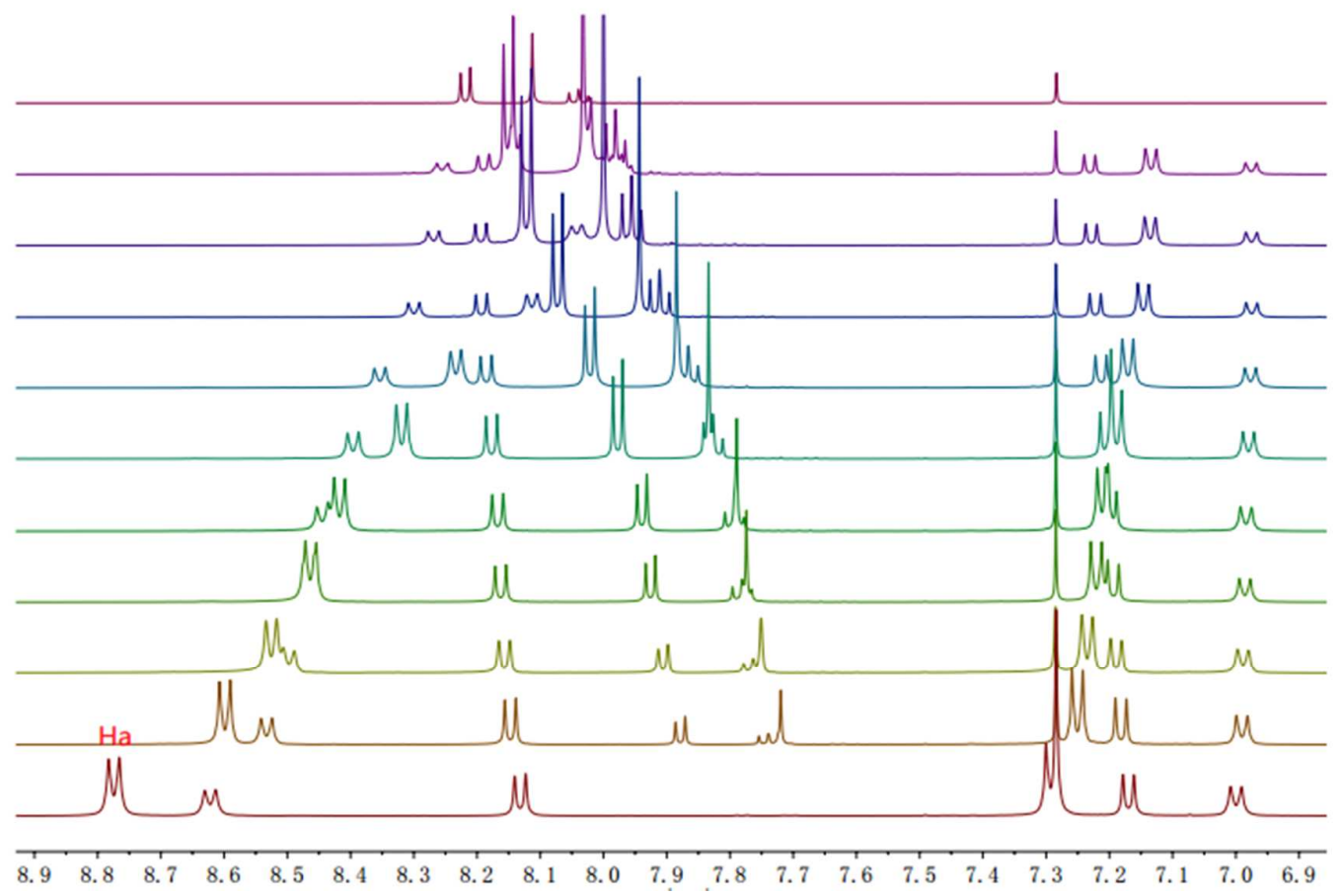

Figure S29. ${ }^{1} \mathrm{H}$ NMR spectra $\left(\mathrm{CDCl}_{3}, 500 \mathrm{MHz}, 298 \mathrm{~K}\right)$ of $\mathbf{1}$ at a concentration of 10 $\mathrm{mM}$ upon addition of $\mathbf{8}$. From bottom to top, the concentrations of 8 were $0.0,4.0,6.0$, $8.0,10,15,20,40,60$, and $80 \mathrm{mM}$, respectively. 


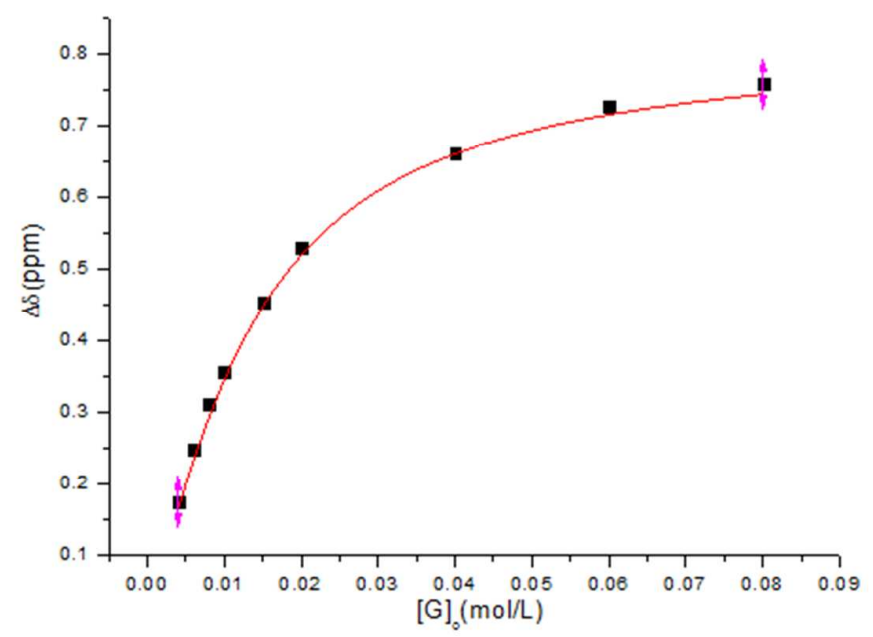

Figure S30. The non-linear curve-fitting (NMR titrations, $\Delta \delta$ of $\mathrm{H}_{\mathrm{a}}$ ) for the complexation of $\mathbf{1}(10.0 \mathrm{mM})$ with $\mathbf{8}$ in $\mathrm{CDCl}_{3}$ at $298 \mathrm{~K}$. The concentration of $\mathbf{8}$ were $0.0,4.0,6.0,8.0,10,15,20,40,60$, and $80 \mathrm{mM}$, respectively. The $K_{\mathrm{a}}$ value for complex $8 \subset 1$ in $\mathrm{CDCl}_{3}$ at $298 \mathrm{~K}$ was determined to be $(1.2 \pm 0.1) \times 10^{2} \mathrm{M}^{-1}$.

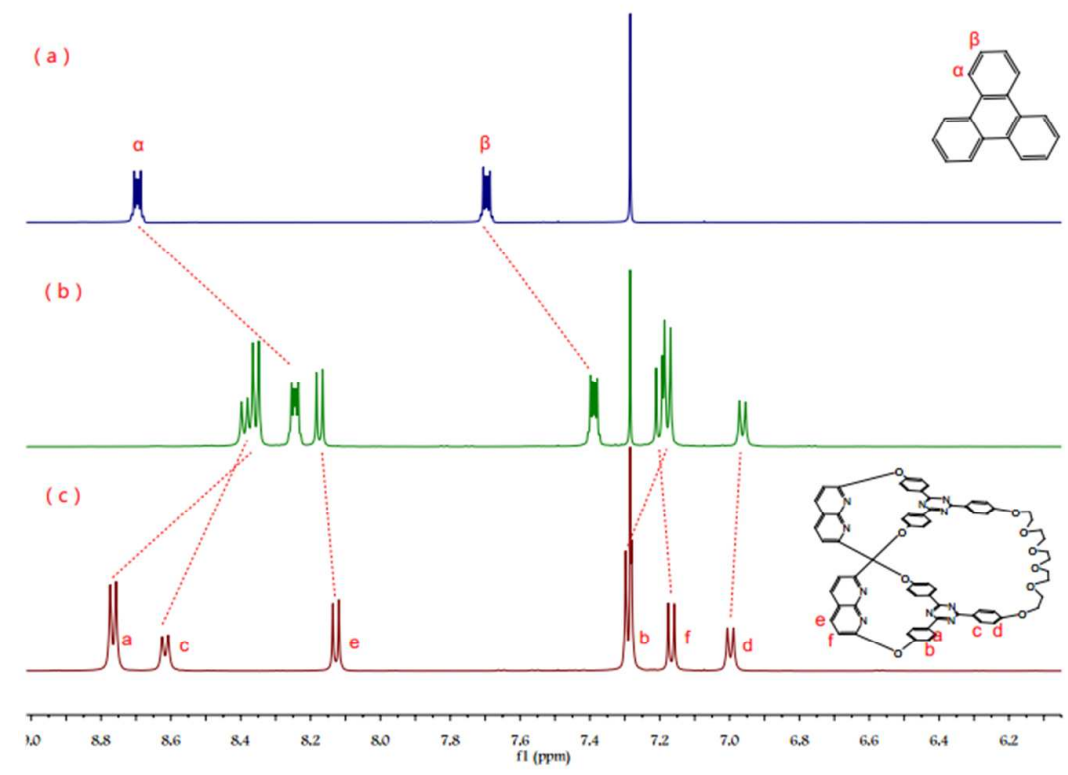

Figure S31. ${ }^{1} \mathrm{H}$ NMR spectra (500 MHz, $\left.\mathrm{CDCl}_{3}, 298 \mathrm{~K}, c=10 \mathrm{mM}\right)$ of: (a) 9, (b) $\mathbf{1}+$ 9, (c) 1 . 


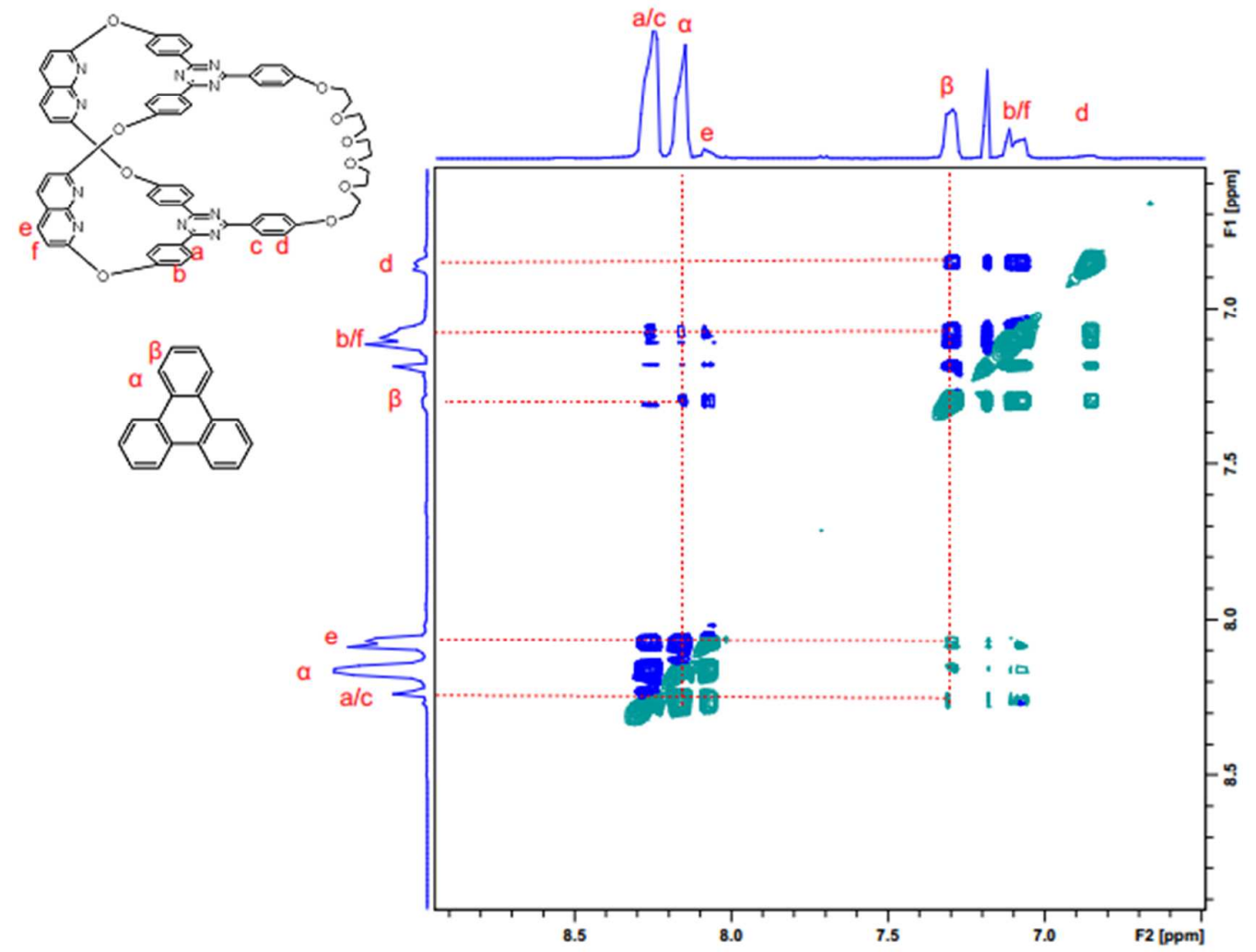

Figure S32. Partial 2D NOESY spectrum of the mixture of $1(10 \mathrm{mM})$ and $9(10 \mathrm{mM})$ in $\mathrm{CDCl}_{3}(400 \mathrm{MHz}, 298 \mathrm{~K})$.

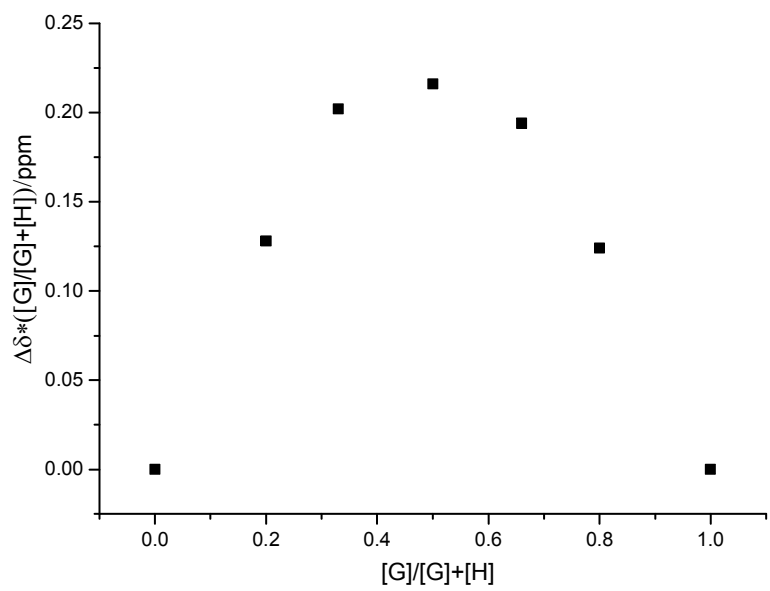

Figure S33. Job plot showing the 1:1 stoichiometry of the complex between 1 and 9 in $\mathrm{CDCl}_{3}$ by plotting the $\Delta \delta$ in chemical shift of 1 's $\mathrm{H}_{\mathrm{a}}$ proton signals observed by ${ }^{1} \mathrm{H}$ NMR spectrum against the molar fraction of complex ([host] + [guest] $=20 \mathrm{mM})$. 


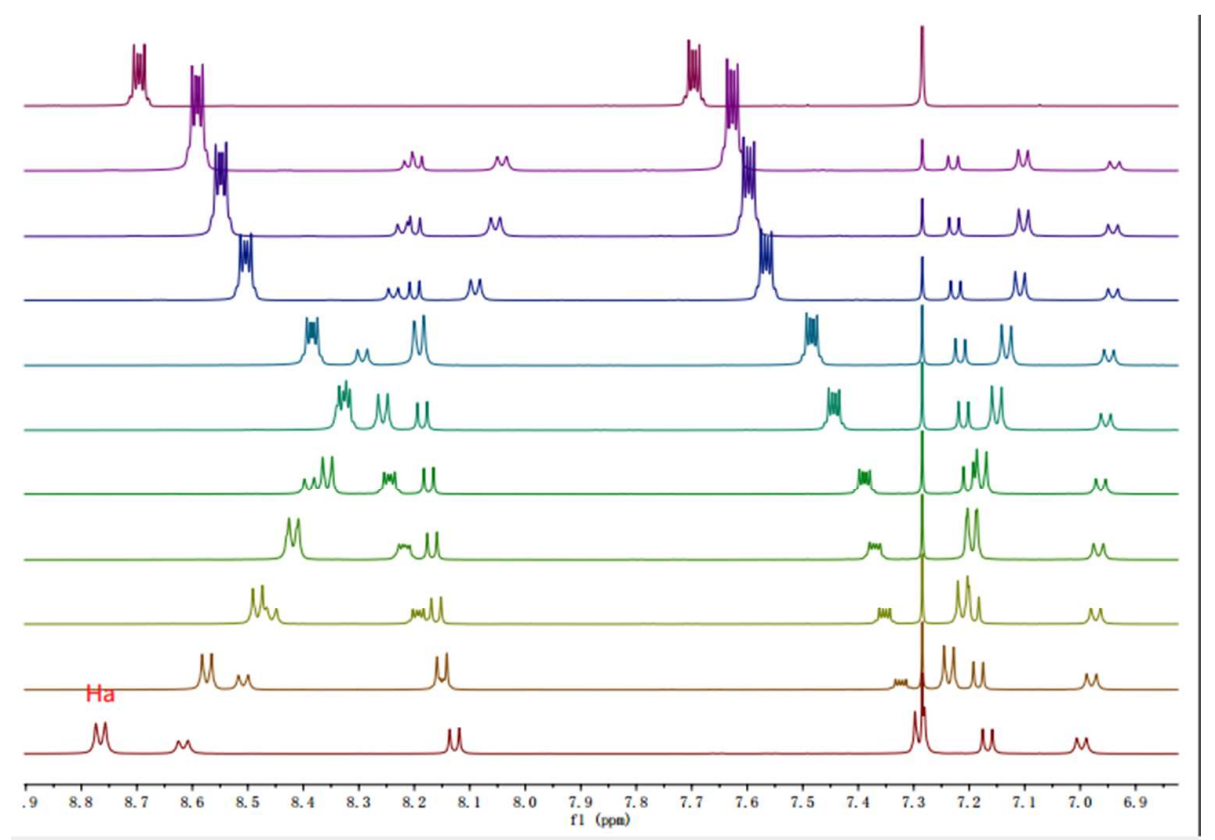

Figure S34. ${ }^{1} \mathrm{H}$ NMR spectra $\left(\mathrm{CDCl}_{3}, 500 \mathrm{MHz}, 298 \mathrm{~K}\right)$ of $\mathbf{1}$ at a concentration of $10.0 \mathrm{mM}$ upon addition of $\mathbf{9}$. From bottom to top, the concentrations of 9 were 0.0 , $4.0,6.0,8.0,10,15,20,40,60$, and $80 \mathrm{mM}$, respectively.

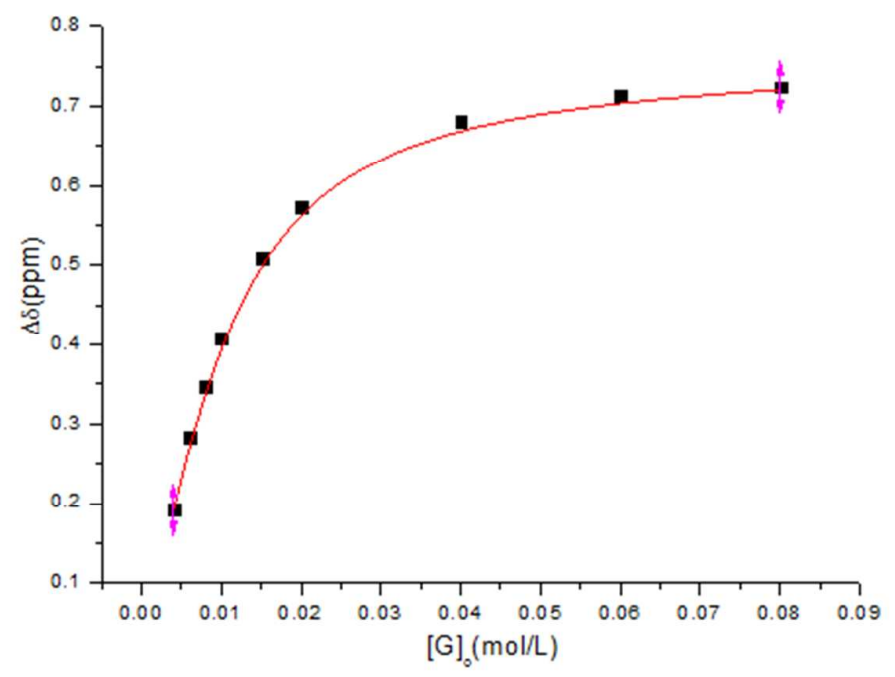

Figure S35. The non-linear curve-fitting (NMR titrations, $\Delta \delta$ of $\mathrm{H}_{\mathrm{a}}$ ) for the complexation of $1(10.0 \mathrm{mM})$ with 9 in $\mathrm{CDCl}_{3}$ at $298 \mathrm{~K}$. The concentration of 9 was $0.0,4.0,6.0,8.0,10,15,20,40,60,80 \mathrm{mM}$. The $K_{\mathrm{a}}$ value for complex $9 \subset 1$ in $\mathrm{CDCl}_{3}$ at $298 \mathrm{~K}$ was determined to be $(2.2 \pm 0.2) \times 10^{2} \mathrm{M}^{-1}$. 


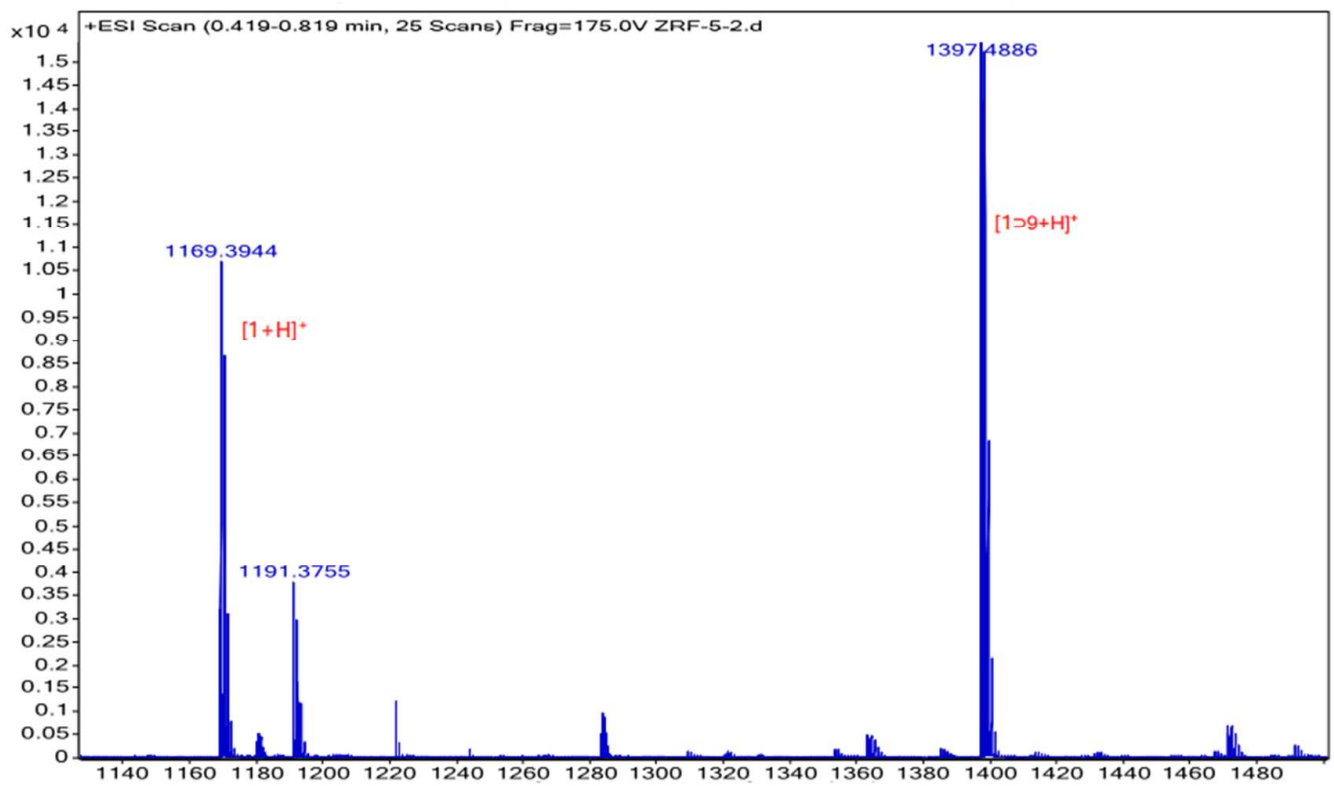

Figure S36. Mass spectrum of host-guest complex $\mathbf{9} \subset \mathbf{1}$. HR-MS calcd for $[\mathbf{9} \subset \mathbf{1}+\mathbf{H}]^{+}$ 1397.4880, found 1397.4886.

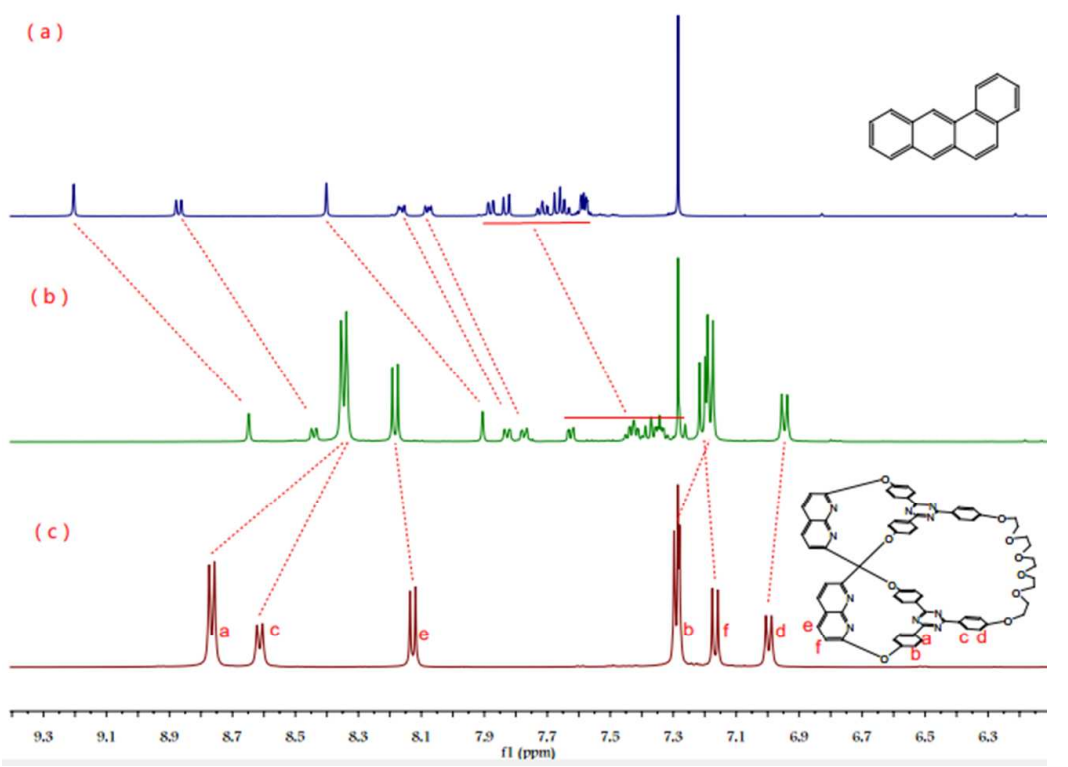

Figure S37. ${ }^{1} \mathrm{H}$ NMR spectra $\left(500 \mathrm{MHz}, \mathrm{CDCl}_{3}, 298 \mathrm{~K}, c=10 \mathrm{mM}\right)$ of (a) 10, (b) $\mathbf{1}$ +10 , (c) 1 . 


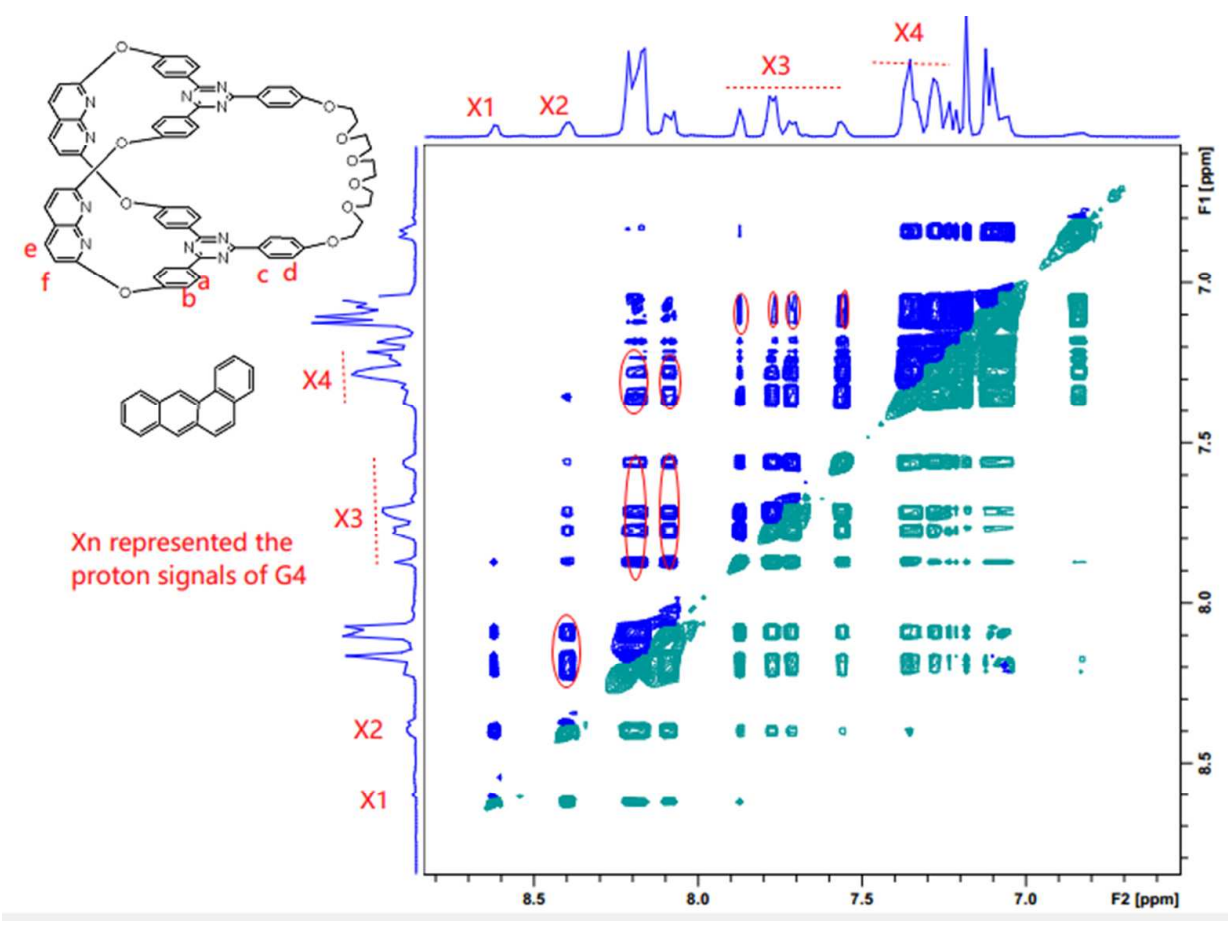

Figure S38. Partial 2D NOESY spectrum of the mixture of $1(10 \mathrm{mM})$ and 10 (10 $\mathrm{mM})$ in $\mathrm{CDCl}_{3}(400 \mathrm{MHz}, 298 \mathrm{~K})$.

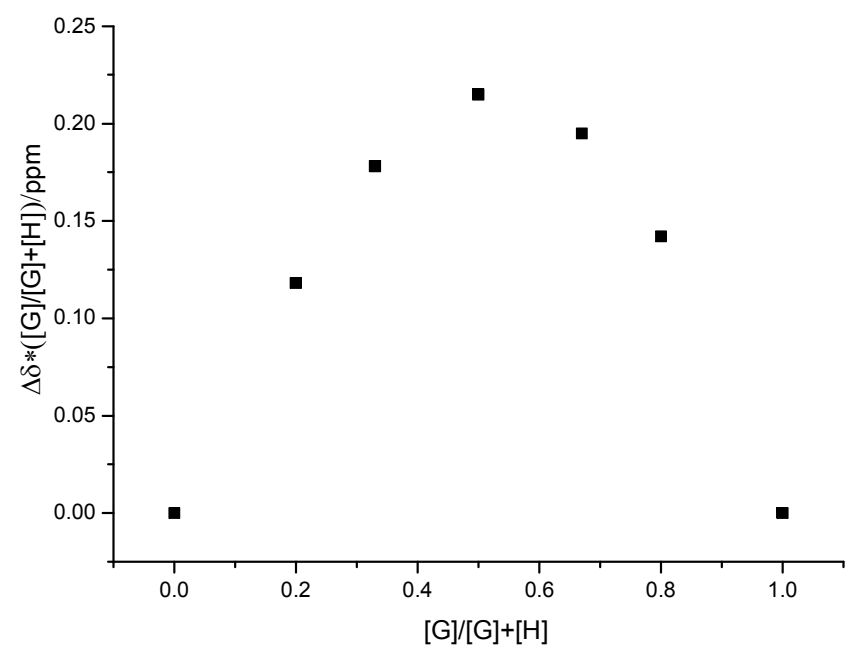

Figure S39. Job plot showing the 1:1 stoichiometry of the complex between $\mathbf{1}$ and $\mathbf{1 0}$ in $\mathrm{CDCl}_{3}$ by plotting the $\Delta \delta$ in chemical shift of 1 's $\mathrm{H}_{\mathrm{a}}$ proton signals observed by ${ }^{1} \mathrm{H}$ NMR spectroscopy against the molar fraction of complex ([host] + [guest] $=20 \mathrm{mM}$ ). 


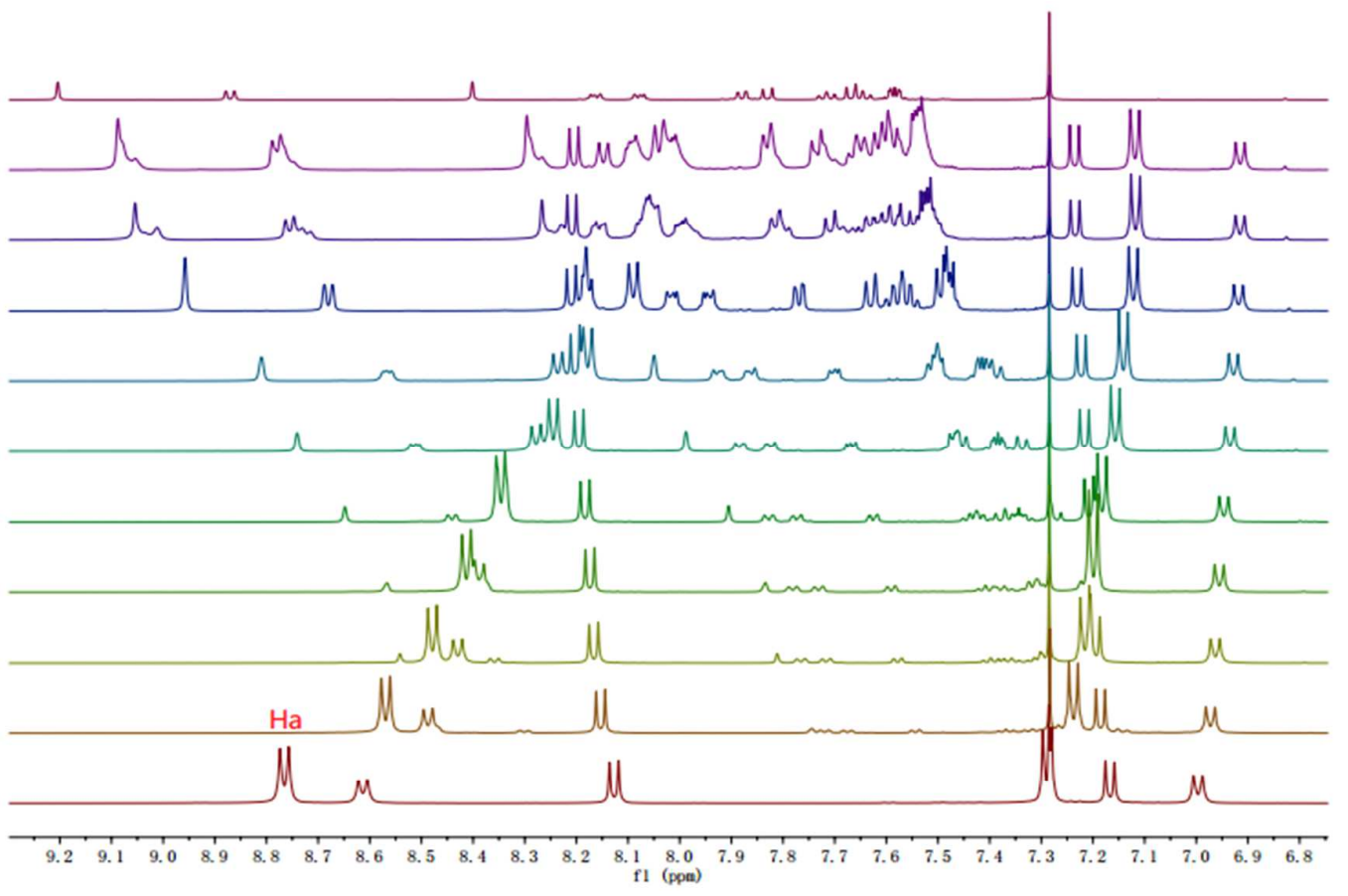

Figure S40. ${ }^{1} \mathrm{H}$ NMR spectra $\left(\mathrm{CDCl}_{3}, 500 \mathrm{MHz}, 298 \mathrm{~K}\right)$ of 1 at a concentration of $10.0 \mathrm{mM}$ upon addition of $\mathbf{1 0}$. From bottom to top, the concentrations of $\mathbf{1 0}$ were 0.0 , $4.0,6.0,8.0,10,15,20,40,60$, and $80 \mathrm{mM}$, respectively.

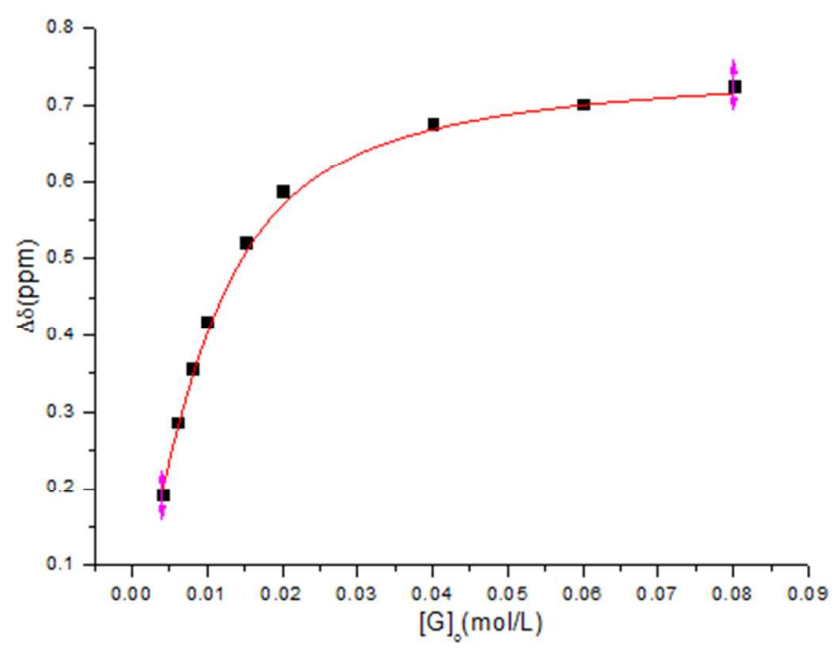

Figure S41. The non-linear curve-fitting (NMR titrations, $\Delta \delta$ of $\mathrm{H}_{\mathrm{a}}$ ) for the complexation of $1(10 \mathrm{mM})$ with $\mathbf{1 0}$ in $\mathrm{CDCl}_{3}$ at $298 \mathrm{~K}$. The concentrations of $\mathbf{1 0}$ were $0.0,4.0,6.0,8.0,10,15,20,40,60$, and $80 \mathrm{mM}$, respectively. The $K_{\mathrm{a}}$ value for complex $\mathbf{1 0} \subset \mathbf{1}$ in $\mathrm{CDCl}_{3}$ at $298 \mathrm{~K}$ is determined to be $(2.4 \pm 0.2) \times 10^{2} \mathrm{M}^{-1}$. 


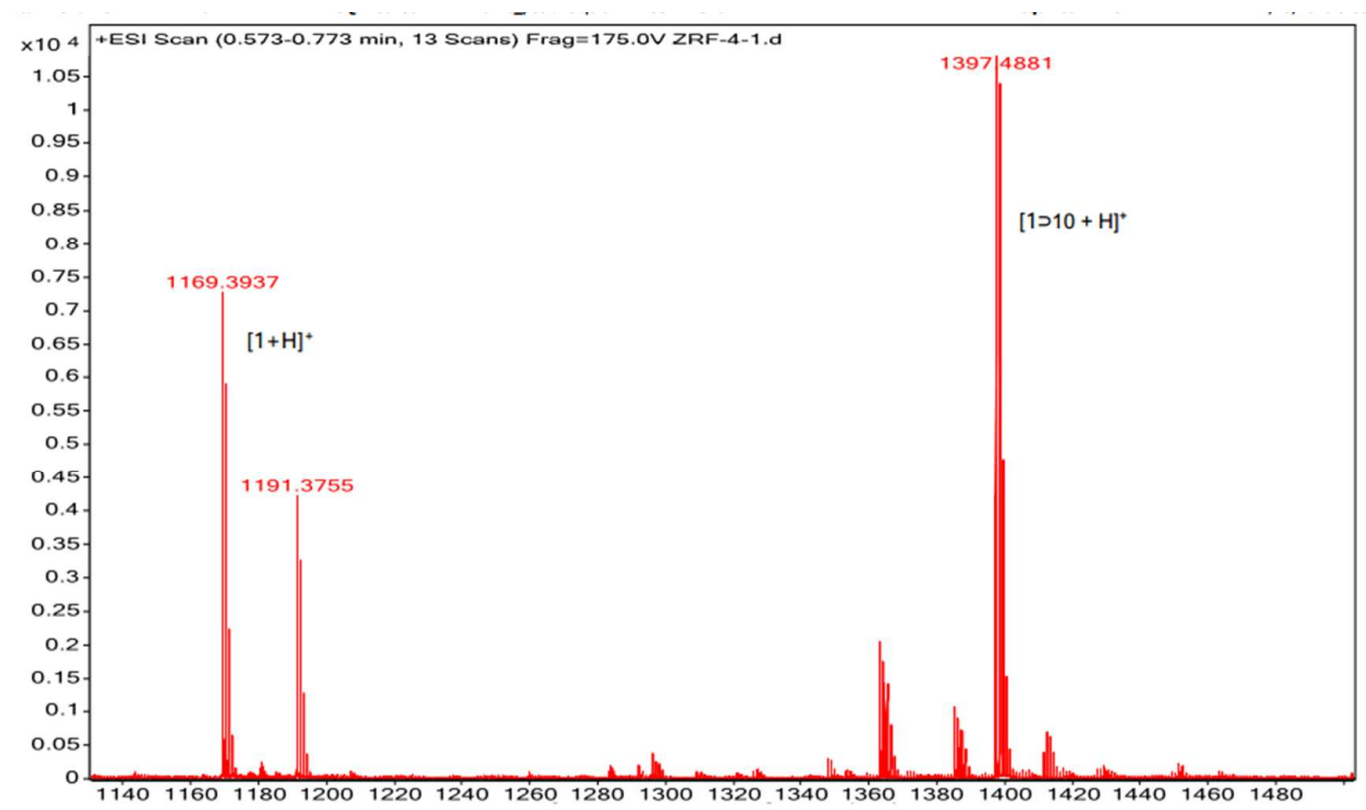

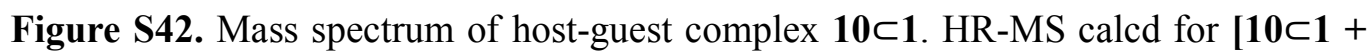
H] ${ }^{+}$1397.4880, found 1397.4881.

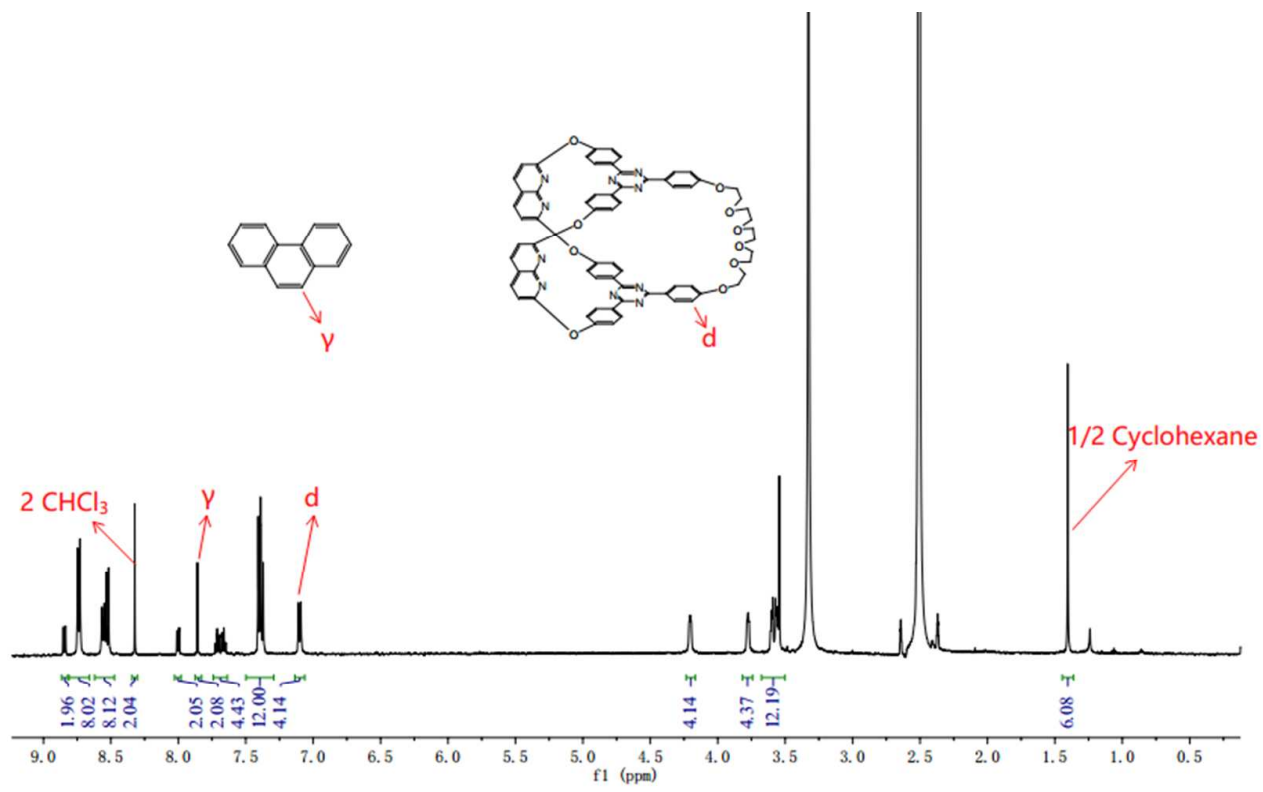

Figure S43. ${ }^{1} \mathrm{H}$ NMR $(500 \mathrm{MHz})$ of the crystals $6 \subset \mathbf{1}$ in DMSO- $d_{6}$. Based on the peak integration, $\mathrm{CHCl}_{3}$ and cyclohexane are included in the crystal lattice with a 1:6: $\mathrm{CHCl}_{3}:$ cyclohexane ratio of $1: 1: 2: 0.5$. 


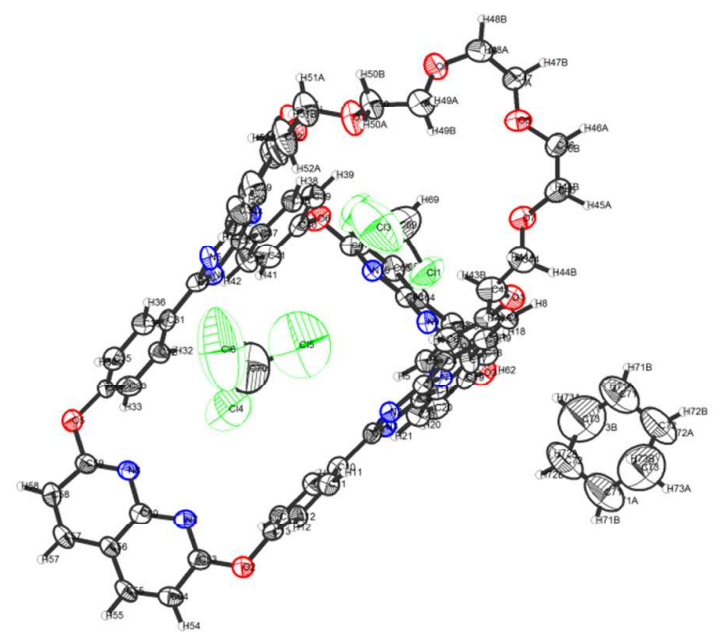

Figure S44. Thermal atomic displacement ellipsoid plot of the structure of crystals of compound 1 grown from $\mathrm{CHCl}_{3}$ and cyclohexane. The ellipsoids of non-hydrogen atoms are drawn at the 50\% probability level. The structures were solved by direct methods and refined by full-matrix least-squares using SHELXS-97. All non-hydrogen atoms were refined anisotropically. Crystal parameters: $\left[\mathrm{C}_{73} \mathrm{H}_{60} \mathrm{C}_{16} \mathrm{~N}_{10} \mathrm{O}_{10}\right] ; M r=1450.01 ; \mathrm{T}=173(2) \mathrm{K}$; Triclinic; space group $P-1 ; a=$ 14.259(3) $\AA ; b=18.033(3) \AA ; c=20.014(4) \AA ; \alpha=65.263(3)^{\circ} ; \beta=87.570(3)^{\circ} ; \gamma=$ $73.367(3)^{\circ} ; V=4460.8(14) \AA^{3} ; Z=2 ; \rho_{\text {calcd }}=1.080 \mathrm{~g} / \mathrm{cm}^{3} ;$ crystal size $=0.200 \mathrm{x}$ $0.170 \times 0.100 \mathrm{~mm} ; \mu=0.245 \mathrm{~mm}^{-1}$; reflections collected 31844 ; unique reflections 19268; data/restraints/parameters 19268/42/893; GOF on $F^{2} 1.133 ; R_{\text {int }}$ for independent data 0.0442 ; final $R_{1}=0.1377, w R_{2}=0.3548 ; \mathrm{R}$ indices (all data) $R_{1}=$ $0.2215, w R_{2}=0.4050$; largest diff. peak and hole: 1.255 and $-1.118 \mathrm{e}^{-3}$. 


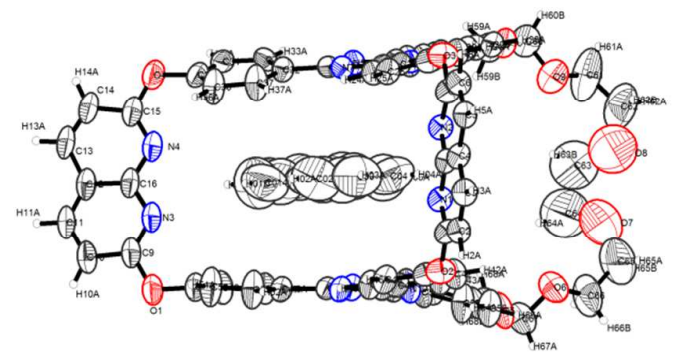

Figure S45. Thermal atomic displacement ellipsoid plot of the structure of crystals of compound $\mathbf{1}+\mathbf{6}$ grown from $\mathrm{CHCl}_{3}$ and cyclohexane. The ellipsoids of non-hydrogen atoms are drawn at the $50 \%$ probability level. The structures were solved by direct methods and refined by full-matrix least-squares using SHELXS-97. All non-hydrogen atoms were refined anisotropically. Solvent molecules were removed in the refinement due to their severe disorder in the crystal lattice. Crystal parameters: $\left[\mathrm{C}_{82} \mathrm{H}_{62} \mathrm{~N}_{10} \mathrm{O}_{10}\right] ; M r=1347.42 ; \mathrm{T}=173(2) \mathrm{K}$; Triclinic; space group $P-1 ; a=$ 14.2186(9) $\AA ; b=18.7376(12) \AA ; c=19.3927(12) \AA ; \alpha=104.395(2)^{\circ} ; \beta=91.811(2)^{\circ}$; $\gamma=92.565(2)^{\circ} ; V=4994.6(5) \AA^{3} ; \mathrm{Z}=2 ; \rho_{\text {calcd }}=0.896 \mathrm{~g} / \mathrm{cm}^{3} ;$ crystal size $=0.42 \mathrm{x}$ $0.36 \times 0.32 \mathrm{~mm} ; \mu=0.060 \mathrm{~mm}^{-1}$; reflections collected 58810 ; unique reflections 17508; data/restraints/parameters $17508 / 416 / 895 ; G O F$ on $F^{2} 0.978 ; R_{\text {int }}$ for independent data 0.0549 ; final $R_{1}=0.1137, w R_{2}=0.3174$; $\mathrm{R}$ indices (all data) $R_{1}=$ $0.1846, w R_{2}=0.3533$; largest diff. peak and hole: 0.981 and $-0.454 \mathrm{e}^{-3}$.

\section{References:}

[1] a) Connors, K. A. Binding Constants, Wiley, New York, 1987. b) Ashton, R. P.; Ballardini, R.; Balzani, V.; Belohradsky, M.; Gandolfi, M. T.; Philp, D.; Prodi, L.; Raymo, F. M.; Reddington, M. V.; Spencer, N.; Stoddart, J. F.; Venturi, M.; Williams, D. J. J. Am. Chem. Soc.1996, 118, 4931-4951. c) Inoue, Y.; Yamamoto, K.; Wada, T.; Everitt, S.; Gao, X.-M.; Hou, Z.-J.; Tong, L.-H.; Jiang, S.-K.; Wu, H.-M. J. Chem. Soc. Perkin Trans. 2, 1998, 1807-1816. 
